\title{
The bushmeat trade in African savannas: impacts, drivers, and possible solutions
}

\author{
Peter Andrew Lindsey ${ }^{\mathrm{a}, \mathrm{b},}$, Guy Balme ${ }^{\mathrm{a}, \mathrm{z}}$, Matthew Becker ${ }^{\mathrm{c}, \mathrm{y}}$, Colleen Begg ${ }^{\mathrm{d}, \mathrm{ab}}$, Carlos Bento ${ }^{\mathrm{e}}$, Clara \\ Bocchino ${ }^{\mathrm{f}}$, Amy Dickman $^{\mathrm{g}}$, Richard W.Diggle ${ }^{\mathrm{h}}$, Heather Eves, ${ }^{\mathrm{i}, \mathrm{a} a}$, Philipp Henschel ${ }^{\mathrm{a}}$, Dale Lewis ${ }^{\mathrm{j}}$, Kelly \\ Marnewick ${ }^{k, a d}$, Jaco Mattheus', J.Weldon McNutt ${ }^{m}$, Rachel McRobb ${ }^{n}$, Neil Midlane ${ }^{a}$, James Milanzio \\ Robert Morley ${ }^{\mathrm{x}}$, Michael Murphree ${ }^{\mathrm{f}}$, Vincent Opyene ${ }^{\mathrm{p}}$, Joe Phadima ${ }^{\mathrm{q}}$, Gianetta Purchase ${ }^{\mathrm{r}, \mathrm{ac}}$, Dennis \\ Rentsch ${ }^{\mathrm{s}}$, Christopher Roche ${ }^{\mathrm{t}}$, Joanne Shaw ${ }^{\mathrm{u}}$, Hugo van der Westhuizen ${ }^{\mathrm{s}}$, Nathalie Van Vliet ${ }^{\mathrm{v}}$, \\ Patience Zisadza-Gandiwaw
}

${ }^{\mathrm{a}}$ Lion Program, Panthera,8 West 40th Street,18th Floor, New York, NY10018, USA

${ }^{\mathrm{b}}$ Mammal Research Institute, University of Pretoria, Private Bag X20, Hatfield, Pretoria 0028, South Africa

${ }^{\mathrm{c}}$ Zambia Carnivore Programme, PO Box 80, Mfuwe, Zambia

${ }^{\mathrm{d}}$ Niassa Carnivore Project, Mozambique e Museu de História Natural, Maputo, Mozambique

${ }^{f}$ North West University, Potchefstroom, South Africa

${ }^{\mathrm{g}}$ University of Oxford, United Kingdom

${ }^{\mathrm{h}}$ WWF in Namibia,Windhoek, Namibia

'College of Natural Resources and Environment, Virginia Tech, Arlington VA, USA

${ }^{\mathrm{j}} \mathrm{COMACO}$, Zambia

${ }^{k}$ Endangered Wildlife Trust, Carnivore Conservation Programme, Private Bag X11, Modderfontein, 1645 Johannesburg, South Africa

'Global Supplies, South Africa

${ }^{m}$ Botswana Predator Conservation Trust, Private Bag 13, Maun, Botswana

${ }^{\mathrm{n}}$ South Luangwa Conservation Society, Mfuwe, Zambia

${ }^{\circ}$ Zambia Wildlife Authority, Chilanga, Zambia

${ }^{\mathrm{p}}$ Uganda Wildlife Authority, Kampala, Uganda

${ }^{\mathrm{q}}$ Ezemvelo Kwa-Zulu Natal Wildlife, Pietermaritzburg, South Africa

${ }^{r}$ Zoological Society of London, London, United Kingdom

${ }^{\mathrm{s}}$ Frankfurt Zoological Society, Serengeti Community Outreach Office, Tanzania

${ }^{\mathrm{t}}$ Wilderness Safaris, Johannesburg, South Africa

${ }^{u}$ TRAFFIC East/Southern Africa, Johannesburg, South Africa

${ }^{\vee}$ University of Copenhagen, Copenhagen, Denmark 
${ }^{\mathrm{w}}$ Zimbabwe Parks and Wildlife Management Authority, Chipinda Pools, Gonarezhou National Park, Zimbabwe

${ }^{x}$ SFM Africa, Johannesburg, South Africa

${ }^{y}$ Department of Ecology, Montana State University, Lewis Hall, Bozeman, MT59717,USA

${ }^{2}$ Department of Zoology, University of Cape Town, Private Bag X3, Rondebosch, 7701, Cape Town, South Africa

${ }^{\text {aa }}$ Department of Biology, Ecology \& Conservation, St.George's University, Caribbean House, Grenada, West Indies

${ }^{a b}$ The Ratel Trust, South Africa

${ }^{\text {ac } W i l d l i f e ~ C o n s e r v a t i o n ~ S o c i e t y, ~ B r o n x, ~ N e w ~ Y o r k, ~ U S A ~}$

${ }^{\text {ad }}$ Centre for Wildlife Management, University of Pretoria, Pretoria 0002, South Africa

*Corresponding author. Tel.:+27 (0)110216727, mobile:+27 (0)82342 7329,+263 (0)778008 410,+260 (0)963750 394; fax:+27 (0)86569 0077. E-mail addresses: plindsey@panthera.org (P.A. Lindsey), gbalme@ panthera.org (G. Balme), matt@zambiacarnivores.org (M. Becker), ratel@iafrica.com (C. Begg), bentomcarlos@yahoo.com.br (C. Bento), clara.bocchino@gmail.com (C. Bocchino), amy.dickman@zoo.ox.ac.uk (A. Dickman), rwdiggle@wwf.na (R.W. Diggle), heather.eve-s@aya.yale.edu (H. Eves), phenschel@panthera.org (P. Henschel), dlewis@wcs.org (D. Lewis), kellym@ewt.org.za (K. Marnewick), jaco@globalsupplies.co.za (J. Mattheus), predatorconservation@ gmail.com (J. Weldon McNutt), rachel@slczambia.org (R. McRobb), neilmidlane@yahoo.co.uk (N. Midlane), jmsmilanzi@yahoo.co.uk (J. Milanzi), murphreemj@gmail.com (M. Murphree), vincent.opyene@gmail.com (V. Opyene), phadimal@kznwildlife.com (J. Phadima), cheetah@zsl.org (G. Purchase), dennisrentsch@fz-s.org (D. Rentsch), chrisr@wilderness.co.za (C. Roche), joannes@ewt.org.za (J. Shaw), hugo@fzs.org (Hugo van der Westhuizen), vanvlietnathalie@yahoo.com (N.V. Vliet), patiencezisadza@gmail.com (P. Zisadza-Gandiwa).

\section{Abstract}

The bushmeat trade, or the illegal acquisition and exchange of wild meat, has long been recognized as a severe problem in forest biomes, but receives little attention in savannas, perhaps due to a misconception that bushmeat hunting is a low-impact subsistence activity. Though data on impacts are scarce, indications are that bushmeat hunting is a widespread problem in savannas, with severe impacts on wildlife populations and wildlife-based land uses. The impacts of the bushmeat trade in savannas vary from edge-effects around protected areas, to disproportionate declines of some species, to severe wildlife declines in areas with inadequate anti-poaching. In some areas, bushmeat contributes significantly to food security, but these benefits are unsustainable, and hunting is 
wasteful, utilizing a fraction of the wildlife killed or of its financial value obtainable through tourism, trophy hunting and/or legal game meat production. The bushmeat trade appears to be becoming increasingly commercialized due to elevated demand in rural areas, urban centres and even overseas cities. Other drivers for the trade include human encroachment of wildlife areas; poverty and food insecurity; and inadequate legal frameworks to enable communities to benefit legally from wildlife, and to create incentives for people to desist from illegal bushmeat hunting. These drivers are exacerbated by inadequate wildlife laws and enforcement and in some areas, political instability. Urgent efforts are needed to address these drivers and raise awareness among local and international governments of the seriousness of the threat. Failure to address this will result in severe wildlife declines throughout the region, with significant ecological, economic and social impacts.

Key words: CBNRM; community; conservation; game meat; poaching; SADC; snaring; trapping

\section{Introduction}

The illegal bushmeat trade is recognized as a major threat to biodiversity in the forests of Central and West Africa (Fa et al., 2003), where it forms a significant component of local and even national economies (Bowen-Jones et al., 2003). Bushmeat contributes significantly to food security, often representing the most important source of protein in rural areas (Nasi et al., 2008), as well as providing a source of cash which is often used to purchase other foods and essentials during lean harvests. However, bushmeat hunting is unsustainable, causing widespread wildlife population declines and extirpation of larger-bodied species (Wilkie, 1999; Fa et al., 2000). Consequently, the current food security benefits associated with bushmeat will falter (Bennett, 2002); supplies from African forests are expected to drop by $81 \%$ over the next 50 years (Fa et al., 2003). The bushmeat trade is thus a crisis from both a conservation and human development perspective. 
In contrast to the situation in forests, the bushmeat trade has received comparatively little attention in African savannas. We define African savannas as being areas that receive $300-1500 \mathrm{~mm}$ of rainfall annually (following Riggio et al. 2012), encompassing a broad array of habitats comprising an area of $\sim 13.5$ million $\mathrm{km}^{2}$. Lack of research focus has perhaps reflected a misconception that bushmeat hunting in savannas is typically a low impact, subsistence phenomenon (Barnett, 2000; Lindsey et al., 2011a). Literature on the bushmeat trade in savannas is limited to a review of the bushmeat trade in southern and East Africa (Barnett, 2000), and sporadic studies in Serengeti National Park (Hofer et al., 2000; Hofer et al., 2000; Loibooki et al., 2002; Marealle et al., 2010), other sites in Tanzania (Nielsen, 2006; Wilfred and MacColl, 2010), Mozambique (Fusari and Carpaneto, 2006; Lindsey and Bento, 2012), Zimbabwe (Gandiwa et al. 2012; Lindsey et al. 2011 a,b) and Zambia (Lewis and Phiri, 1998; Lewis, 2005; Brown, 2007; Lewis et al., 2011; Becker et al., 2012). While these studies demonstrate significant negative ecological impacts, the drivers, impacts and interventions needed to address the bushmeat trade in savannas are not well understood.

Lack of research and actions to address the bushmeat trade to date may reflect an underappreciation of the problem's significance among contemporary governments, wildlife agencies, and non-governmental organizations in the region. Recently, however, the bushmeat issue received recognition that extended beyond forest biomes, when the Convention on Biological Diversity (CBD) established a liaison group on bushmeat (Secretariat of the Convention on Biological Diversity, 2011). In addition, growing concern over the impacts of the bushmeat trade in savannas catalyzed a meeting of conservation practitioners to brainstorm the issue in May 2012. This paper summarizes existing knowledge and the recommendations that emanated from the meeting. 


\section{Methods}

Participants for the meeting were selected based on known involvement in issues relating to the bushmeat trade in African countries encompassing savannas. The 29 attendees provided insights and experience from 18 African countries.

To describe the bushmeat hunting methods in savanna systems, a literature search was conducted using Web of Science ${ }^{\circledR}$ and search terms such as: bushmeat trade; bows; arrows; dogs; firearms; gin traps; hunting; poaching; snaring; trapping. The legality of hunting methods was assessed for 16 countries in the savanna biome by reviewing legislation derived from http://faolex.fao.org/faolex/index.htm (accessed June 2012). Information on the prevalence of various hunting methods, reasons and drivers for bushmeat hunting, and impacts on wildlife populations were gleaned from the literature and from the collective expertise, experience and data of the meeting attendees.

\section{Bushmeat hunting and the law}

In most African countries, hunting is regulated by legal instruments, with harvests being controlled through systems of licensing and quotas. In terms of ownership, wildlife is generally either considered to be 'res nullius' (without ownership) or belonging to the state or president. In southern Africa, however, varying degrees of ownership or user-rights are allocated to private (and in some instances, communal) landholders under conditions that vary from country to country, such as: following application for a quota (e.g. Zimbabwe, communal lands in Namibia); erection of fencing (e.g. South Africa, Botswana, Zambia); application for permits for the use of certain species (e.g. Namibia, South Africa); application for a temporary certificate of ownership (Zambia) (Barnett \& Patterson, 2006; Cirelli and Morgera, 2009; Lindsey et al., In press). Using these user-rights, private land owners either hunt wildlife for their own use, or sell hunting rights to hunting operators or 
tourists (Bond et al., 2004). Rights to hunt for trophies on communal and state lands are typically sold to private safari operators according to quotas (Lindsey et al., 2007). In some countries, e.g. Zambia, Tanzania, Botswana and Malawi, hunting licenses are allocated to citizens to hunt for meat, and in some scenarios subsistence hunting is allowed without a permit on certain categories of land (e.g. Malawi, Angola and Mozambique) (Cirelli and Morgera, 2009).

Hunting laws typically stipulate restrictions on the times of year that hunting is permitted, prohibitions on hunting in certain protected areas, hunting certain species, young or pregnant animals, on the use of certain hunting methods and without permits (Table 1) (Cirelli and Morgera, 2009). Hence, bushmeat hunting is illegal in most contexts within which it occurs, due to contravention of one or more of these restrictions. The meat obtained from illegal hunting is referred to as "bushmeat" to prevent confusion with legal harvest of wildlife for "game meat".

\section{Bushmeat hunting methods}

Snares are the most common method used by bushmeat hunters (Table 2). Snares typically comprise a noose, usually attached to trees along trails (Hofer et al., 1996). Animals are caught when they put their head (or a leg) into the snare and pull it tight (Noss, 1998). Snares can be made from natural fibre, nylon or wire. Increasingly wire for snares is widely available from telephone and electricity lines, fencing, bicycle brakes and burnt tyres (Hofer et al., 1996; Lindsey et al., 2011a; Becker et al. 2012). Snares are cheap, difficult to detect and can cause rapid declines in wildlife populations (Lindsey et al., 2011a). They can catch species ranging from rodents to elephants (Loxodonta africana) depending on the snare size and material (Hofer et al., 1996; Noss, 1998; Hofer et al., 2000). Snares are unselective and frequently kill non-target animals (Lindsey et al., 2011a; Becker et al., 2012). Because of the low value of snares, hunters often check them infrequently, causing wastage (Noss, 1998). For example, in Zimbabwe's Savé Valley Conservancy, at least 1,410 animals 
Table 1. The legality of various bushmeat hunting methods in 15 African countries ${ }^{\text {a }}$

\begin{tabular}{|c|c|c|c|c|c|c|c|c|}
\hline Country & Fire & Snares & Poison & $\begin{array}{c}\text { Automatic } \\
\text { weapons }\end{array}$ & Dogs & Nets & Traps & Reference \\
\hline Benin & 0 & 0 & 0 & 0 & 0 & 0 & 0 & $\begin{array}{l}\text { Loi no } 87-014 \text { portant réglementation de la protection de la nature et de } \\
\text { l'exercice de la chasse en République Populaire du Bénin } \\
\text { Décret N 96-061, portant réglementation de l'exploitation de la faune. Loi }\end{array}$ \\
\hline Burkina Faso & 0 & 0 & 0 & 0 & 1 & 1 & 0 & $\begin{array}{l}\text { N 006/97/ADP du } 31 \text { janvier } 1997 \text { Portant Code Forestier } \\
\text { Loi no 94/01 portant régime des forêts, de la faune et de la pêche ( } 20\end{array}$ \\
\hline Cameroon & 0 & ? & 0 & 0 & 0 & $0^{b}$ & 1 & $\begin{array}{l}\text { January 1994) ; Décret no } 95-466 \text { fixant les modalités d'application du } \\
\text { régime de la faune } \\
\text { Ordonnance No. } 84.045 \text {, portant protection de la faune sauvage et }\end{array}$ \\
\hline Central African Republic & 0 & 0 & 0 & 0 & 0 & 0 & 0 & $\begin{array}{l}\text { réglementant l'exercice de la chasse } \\
\text { Ordonnance no } 14-63 \text { du } 28 \text { mars } 1963 \text { réglementant la chasse et la }\end{array}$ \\
\hline Chad & 0 & 0 & 0 & 0 & 0 & 0 & 0 & protection de la nature \\
\hline Botswana & 0 & 0 & 0 & 0 & 1 & 0 & 0 & Wildlife Conservation and National Parks Act, 1992 \\
\hline Mozambique & 0 & 0 & 0 & 0 & 1 & 0 & 0 & Forest and Wildlife Act (No. 10/1999) \\
\hline Namibia & 0 & 0 & 0 & 0 & 0 & 0 & 0 & $\begin{array}{l}\text { Namibia Nature Conservation Ordinance, } 1975 \\
\text { Loi № } 98-07 \text { du } 29 \text { avril } 1998 \text { fixant le Régime de la Chasse et de la }\end{array}$ \\
\hline Niger & 0 & 0 & 0 & 0 & 0 & 0 & 0 & $\begin{array}{l}\text { Protection de la Faune } \\
\text { Code de la chasse et de la Protection de la faune. Loi N 86-04 du janvier }\end{array}$ \\
\hline Senegal & 0 & 0 & 0 & 0 & 0 & 0 & 0 & 1986. Décret N 86-844 du juillet 1986 \\
\hline Sudan & 0 & 0 & 0 & 0 & 0 & 0 & 0 & Wildlife Conservation and National Parks Act, 2003 \\
\hline Tanzania & 0 & 0 & 0 & 0 & 0 & 0 & 0 & Wildlife Conservation Act, 2009 \\
\hline Zambia & 0 & 0 & 0 & 0 & 0 & 0 & 0 & Zambia Wildlife Act, No.12 of 1998 \\
\hline Zimbabwe & 0 & 0 & 0 & 0 & 1 & 0 & 0 & Trapping of Animals (Control) Act (2002) \\
\hline Average & 0 & 0 & 0 & 0 & 0.27 & 0.13 & 0.6 & \\
\hline
\end{tabular}

${ }^{a}$ The legality of hunting with single-shot firearms, muzzle-loading firearms, shot guns and bows and arrows is more complex as these methods are legal under some circumstances in some countries, albeit when in possession of the necessary permits and in some cases given specific calibres/bow strengths for particular species.

b 'Modern' nets prohibited 
rotted in snares during 2001-2009 (Lindsey et al., 2011a). Finally, there are animal welfare issues associated with snares as they cause slow deaths and high rates of non-fatal wounding (Noss, 1998).

Dogs are often used by hunters to bay wildlife (Jachmann, 2008a; Grey-Ross et al., 2010) (Table 2). In some areas firearms are used, though automatic weapons are rarely used (Fusari 2001; Brown, 2007). In Mozambique, bushmeat hunters commonly use gin traps manufactured from vehicle leafsprings to kill animals as large as buffalo Syncerus caffer and elephant (Fusari 2001; Lindsey \& Bento 2012). Fire is used by hunters to flush wildlife, clear undergrowth, increase visibility, stimulate greengrowth which concentrates wildlife, and cover tracks (Lindsey and Bento, 2012).

\section{Spatial and temporal patterns in bushmeat hunting}

With wildlife disappearing from unprotected lands (Newmark, 2008), illegal hunters are increasingly focusing their efforts on protected areas. Within protected areas, bushmeat hunting is more prevalent close to the borders and near human settlements (Muchaal and Ngandjui, 1999; Hofer et al., 2000; Wato et al., 2006; Marealle et al., 2010). Greater distances mean increased time, effort and costs for hunters to find wildlife and transport meat, and higher risk of apprehension (Hofer et al., 2000). Bushmeat hunters typically focus efforts in areas where wildlife concentrates, such as near water, game trails, green-flushes or flowering/fruiting trees (Lindsey and Bento, 2012; Becker et al., 2012).

There are consistent temporal patterns in bushmeat hunting, with peaks in the late dry season when wildlife concentrates around water (Brown, 2007; Holmern et al., 2007; Lindsey et al., 2011a), and following poor crop harvests (Lindsey et al., 2011a), and lulls during peak agricultural activity when hunters are often otherwise occupied (Knapp, 2007; Brashares et al., 2011). In the Serengeti, bushmeat hunting increases during the wildebeest (Connochaetes taurinus) migration (Holmern et 
Table 2. The prevalence of methods used to hunt wildlife for bushmeat in savanna Africa (NB that in cases where information was sourced from literature, it may be the case that some hunting methods are used in the study areas but were not mentioned in the papers by the authors)

\begin{tabular}{|c|c|c|c|c|c|c|c|c|c|c|}
\hline Area & Snares & Firearms & Dogs & Fire & $\begin{array}{l}\text { Bows } \\
\& \\
\text { arrows }\end{array}$ & $\begin{array}{l}\text { Gin } \\
\text { traps }\end{array}$ & Nets & $\begin{array}{l}\text { Small } \\
\text { mammal } \\
\text { /bird } \\
\text { traps }\end{array}$ & $\begin{array}{l}\text { Pit } \\
\text { fall } \\
\text { traps }\end{array}$ & Source \\
\hline Hunting concessions near Okavango, Botswana & 1 & 1 & 1 & 1 & 0 & 0 & 0 & 0 & 0 & K. Collins, unpublished data \\
\hline Tsavo National Park, Kenya & 1 & 0 & 0 & 0 & 0 & 0 & 0 & 0 & 0 & (Wato et al., 2006) \\
\hline Sokoke Forest, Kenya & 0 & 0 & 1 & 0 & 1 & 0 & 0 & 1 & 0 & (Fitzgibbon et al., 1995) \\
\hline WAP complex, Benin, Burkina Faso, Niger & 0 & 1 & 0 & 1 & 0 & 1 & 0 & 0 & 0 & P Henschel unpublished data \\
\hline Comoé NP, Ivory coast & 0 & 1 & 0 & 1 & 0 & 1 & 0 & 0 & 0 & P Henschel unpublished data \\
\hline Batéké Plateau, SE Gabon & 1 & 1 & 1 & 1 & 0 & 0 & 1 & 1 & 0 & P Henschel unpublished data \\
\hline Gile Game Reserve, Mozambique & 1 & 0 & 0 & 1 & 0 & 1 & 1 & 0 & 0 & (Fusari and Carpaneto, 2006) \\
\hline Coutada 9, Mozambique & 1 & 1 & 0 & 1 & 1 & 1 & 0 & 0 & 0 & (Lindsey and Bento, 2012) \\
\hline Niassa, Mozambique & 1 & 1 & 1 & 1 & 0 & 0 & 1 & 1 & 1 & C. Begg, unpublished data \\
\hline Pafuri, South Africa & 1 & 0 & 1 & 0 & 0 & 1 & 0 & 0 & 0 & C. Roche, unpublished data \\
\hline Dwesa / Cwebe Reserves, RSA & 1 & 1 & 1 & 0 & 0 & 0 & 0 & 0 & 0 & (Hayward, 2009) \\
\hline Munyawana Game Reserve, RSA & 1 & 1 & 1 & 0 & 0 & 0 & 0 & 0 & 0 & J. Mattheus unpublished data \\
\hline Ruaha ecosystem, Tanzania & 1 & 1 & 1 & 0 & 1 & 1 & 0 & 1 & 0 & A. Dickman unpublished data \\
\hline Serengeti National Park, Tanzania & 1 & 0 & 1 & 1 & 1 & 0 & 0 & 1 & 1 & D. Rentsch unpublished data \\
\hline North western Tanzania & 1 & 1 & 0 & 1 & 1 & 0 & 0 & 0 & 0 & (Jambiya et al., 2007) \\
\hline North Luangwa National Park, Mukungule, Munyamadzi, and W/E Musalangu game management areas & 1 & 1 & 0 & 0 & 0 & 0 & 0 & 0 & 0 & (van der Westhuizen, 2007) \\
\hline South Luangwa National Park, Upper and Lower Lupande, and Sandwe game management areas, & & & & & & & & & 0 & D. Lewis, R. McRobb, unpublished \\
\hline Zambia & 1 & 1 & 1 & 0 & 0 & 0 & 0 & 0 & & data, (Becker et al., In press) \\
\hline Kafue National Park, Zambia & 1 & 1 & 0 & 1 & 0 & 0 & 0 & 0 & 0 & N.Midane, unpublished data \\
\hline Private conservancies, Zimbabwe & 1 & 0 & 1 & 0 & 1 & 0 & 1 & 0 & 0 & $\begin{array}{l}\text { (Lindsey et al., 2012) } \\
\text { H. van der Westhuizen, }\end{array}$ \\
\hline Gonarezhou National Park, Zimbabwe & 1 & 0 & 1 & 1 & 1 & 0 & 1 & 0 & 0 & unpublished data, Gandiwa 2011 \\
\hline Average & 0.85 & 0.65 & 0.6 & 0.55 & 0.35 & 0.3 & 0.25 & 0.25 & 0.1 & \\
\hline
\end{tabular}


al., 2007). Hunters using dogs are most active during moonlight when it is easy to see, and on rainy nights (Lindsey et al., 2011a; J. Mattheus, pers. comm.).

\section{Scale of the bushmeat trade}

Sporadic (though largely meaningless) insights into the volumes of bushmeat traded are provided in the literature. For example; in Tanzania, 2,078 tonnes of bushmeat are confiscated annually with a value of $>$ US\$50 million; in Central African Republic, an estimated 59,000 tonnes of bushmeat are sold illegally each year; and in Mozambique 182,000-365,000 tonnes are consumed annually, with an economic value of US\$365-730 million/year (Barnett, 2000; Secretariat of the Convention on Biological Diversity, 2011). The authors quoting those figures do not indicate whether those quantities are traded on a once off or ongoing basis, or shed light into trends in the scale of the trade. Accurately quantifying the amount of wildlife hunted or the quantity bushmeat traded is extremely difficult given the illicit nature of the activities and lack of research on the topic in savannas.

\section{Impact of bushmeat hunting}

\subsection{Ecological impacts}

Wildlife populations are declining in most African countries (Craigie et al., 2010; Scholte, 2011) and bushmeat hunting is a key contributor. In Kenya and Zambia, for example, bushmeat hunting has emerged as the primary threat to wildlife (Barnett, 2000; Okello and Kiringe, 2004). From our sample of 25 case studies (which often incorporate multiple sites, and providing insights from 14 countries), the impacts of bushmeat hunting on wildlife appear to fall into three categories (Table 3). 
Table 3. Impacts on illegal hunting observed in multiple sites from the literature and a survey of $n=12$ attendees at a bushmeat meeting

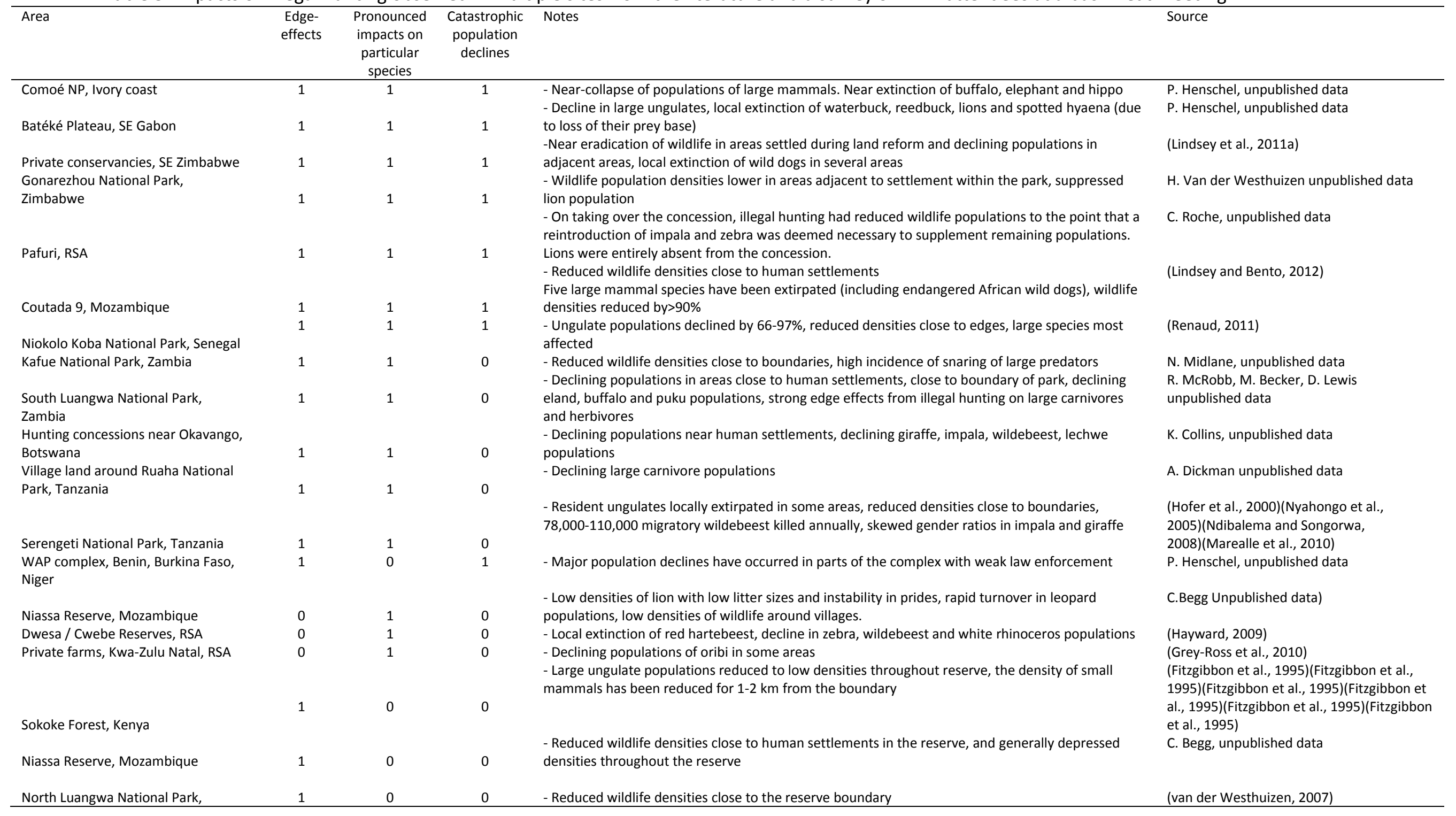




\begin{tabular}{|c|c|c|c|c|c|}
\hline \multicolumn{6}{|l|}{ Zambia } \\
\hline North western Tanzania & 0 & 0 & 1 & $\begin{array}{l}\text { - Wildlife populations in Burigi and Biharamulo Game Reserves were reduced to less than } 10 \% \text { of } \\
\text { their former numbers largely through illegal exploitation by refugees and local populations }\end{array}$ & (Jambiya et al., 2007) \\
\hline Ranches in the Kalahari ecoregion of & & & & - Reductions of wildlife populations of up to $90 \%$ due to excessive harvests to supply the bushmeat & (du Toit, 2004) \\
\hline north western Zimbabwe & 0 & 0 & 1 & trade following the settlement of ranches during land reform & \\
\hline & & & & - Dramatic declines $(50-60 \%)$ in antelope populations during the $1-2$ years following the land reform & (du Toit, 2004) \\
\hline $\begin{array}{l}\text { Agricultural farms on the Zimbabwe } \\
\text { central plateau }\end{array}$ & 0 & 0 & 1 & $\begin{array}{l}\text { programme, due to excessive off-takes for the bushmeat trade, } 50 \% \text { loss of national tsessebe } \\
\text { population }\end{array}$ & \\
\hline Game management areas, Zambia & 0 & 0 & 1 & $\begin{array}{l}\text { - } 24 \text { out of } 36 \text { game management areas (which collectively cover } 170,000 \mathrm{~km}^{2} \text { ) are 'under-stocked' } \\
\text { or 'depleted', due primarily to illegal bushmeat hunting }\end{array}$ & (Simasiku et al., 2008) \\
\hline Northern Central African Republic & 0 & 0 & 1 & $\begin{array}{l}94 \% \text { decline in large mammal populations over } 30 \text { years, across an area of } 95,000 \mathrm{~km}^{2} \\
90-100 \% \text { population declines due to hunting for bushmeat and trophies during and after the civil }\end{array}$ & $\begin{array}{l}\text { (Bouché et al., 2012) } \\
\text { (Hatton et al., 2001) }\end{array}$ \\
\hline Gorongosa National Park, Marromeu & & & & war, several other reserves severely depleted but lacking 'before' data to make quantitative & \\
\hline Buffalo Reserve, Mozambique & 0 & 0 & 1 & assessments & \\
\hline Average & 0.64 & 0.60 & 0.56 & & \\
\hline
\end{tabular}


a) Edge-effects, including reduced effective park sizes and depressed wildlife densities close to human settlements (recorded in $64 \%$ of case-studies) (Table 3). Impacts of bushmeat hunting are exacerbated by the use of fire by hunters, which reduce dry-season grazing, and force wildlife from protected areas in search of grazing.

b) Disproportionate impacts on particular species, which can have severe consequences for ecosystem services (e.g. seed dispersal and predation) (Wright et al., 2007; Brodie et al., 2009). Such impacts were recorded in $60 \%$ of case-studies (Table 3). Large species are generally targeted by bushmeat hunters, and declining populations are reflected in their waning prevalence in bushmeat markets (Barnett, 2000). Wide-ranging predators are particularly affected by snaring, because they are attracted to carcasses of trapped animals and are also impacted by declining prey populations (Table 3).

c) Dramatic, generalized wildlife population declines have occurred at a number of sites where largescale bushmeat hunting has been allowed to proceed in the absence of effective law enforcement (Table 3). For example, wildlife populations in Central and West African savannas are collapsing due to excessive bushmeat hunting (Fischer and Linsenmair, 2001; Renaud, 2011; Bouché et al., 2012) (Table 3). In some countries, vast wildernesses exist where wildlife has been depleted, and empty savannas are as real as 'empty forests' (Redford, 1992; Bouché et al., 2012). In Zambia, for example, wildlife populations have been severely depleted in $70 \%$ of game management areas (comprising $170,000 \mathrm{~km}^{2}$ ), largely through excessive bushmeat hunting (Simasiku et al., 2008). In some areas bushmeat hunting represents a more severe threat than habitat loss (Wilkie et al., 2011), and the two issues often act synergistically, with severe ecological consequences (Ogutu et al., 2009; Wilkie et al., 2011).

Available data preclude rigorous quantification of the ecological impact of bushmeat beyond that allowed for by the available case-studies. However, we are confident that the case-studies in Table 3 represent a tiny fraction of the areas in savannas that are severely impacted by bushmeat hunting. 
Furthermore, one can expect the impacts to increase in future: as wildlife disappears from humandominated landscapes, off-takes will focus increasingly on protected areas, resulting in greater proportional impacts on those populations. The scale and apparent ubiquity of the threat posed by bushmeat hunting suggests that without urgent intervention, wildlife resources will be lost in many areas with severe economic and social impacts in addition to the ecological implications.

\subsection{Economic and social impacts}

Bushmeat hunting can reduce the viability of and even preclude wildlife-based land uses. Trophy hunting is financially unviable in many concessions (18.8-92.3\% depending on the country) due to bushmeat hunting (Lindsey et al., 2012). For example, bushmeat hunting reduced trophy hunting income by $96 \%$ in Coutada 9 (Mozambique), by $67 \%$ in Burigi and Biharamulo Game Reserves in Tanzania, and by US\$1.1 million per year in Savé Valley Conservancy (Jambiya et al., 2007; Lindsey et al., 2011a; Lindsey and Bento, 2012). Ecotourism operations are even more sensitive to bushmeat hunting as they require higher densities of wildlife (Wilkie and Carpenter, 1999). For example, in the Makuleke concession of Kruger National Park, ecotourism operators incurred losses for the first six years of operation as wildlife recovered from previously high levels of bushmeat hunting (which was reflected by the removal of $>2,000$ snares during the first two years of operations) (C. Roche, pers. comm.).

Social consequences of illegal bushmeat trade include negative impacts on food security in the long term through the loss of a potentially sustainable and greatly elevated supply of meat protein through legal wildlife-based land uses, the loss of tourism-based employment and the loss of wildlife heritage. In some cases, bushmeat hunting is done primarily by communities living away from wildlife populations, with the effect that the people bearing the costs of living with wildlife are not those who benefit from bushmeat (van der Westhuizen, 2007). 


\section{Bushmeat hunters and traders}

Hunting is an almost exclusively male activity, though women often butcher meat (Brown, 2007; Lindsey et al., 2011b). Where hunting grounds are distant from hunters' homes, meat carriers are employed (Brown, 2007). In many cases, bushmeat hunters are poor, unemployed, with little education and few livestock (Loibooki et al., 2002; Knapp 2007; Lindsey et al., 2011b). Bushmeat hunting can be lucrative, however, and in Tanzania, hunters are wealthier than non-hunters (Knapp, 2007). Similarly, in Zambia, some hunters earn nearly US\$100 from a single expedition, which approaches the mean per capita annual income for citizens of US\$120, and hunters are among the wealthiest community members (Brown, 2007). In some cases, hunters enjoy elevated social status as a result of their profession (Brown, 2007) and are preferred by women (D. Rentsch unpublished data).

Bushmeat hunting is rarely practised purely for subsistence and operates on a continuum from provisioning meat for local consumption and trade, up to providing meat for urban or even international markets (Brashares et al., 2011) (Table 4). In several southern and East African countries, well-developed and complex rural-urban trade supply networks exist (Barnett, 2000). Outlets for the sale of bushmeat, such as open-air markets, chop-bars and butcheries, have arisen in some areas, and full-time commercial bushmeat traders occur in most southern and East African countries (Barnett, 2002). In the Serengeti area for example, 34.3\% of traders rely on bushmeat as their sole source of income, and sell meat up to $200 \mathrm{~km}$ away (Barnett, 2000). In central Mozambique, middlemen purchase bushmeat from hunters to re-sell in urban centres (Lindsey and Bento, 2012). Bushmeat is dried or smoked for preservation, and transported to urban markets via foot, bicycle, vehicle or train (Edderai and Dame, 2006; Lindsey et al., 2011a). 
Table 4. The most common reasons for bushmeat hunting in various savanna sites in Africa

\begin{tabular}{|c|c|c|c|c|c|c|c|}
\hline Area & $\begin{array}{c}\text { Own } \\
\text { use }\end{array}$ & Local commercial trade & $\begin{array}{c}\text { Commercial trade to } \\
\text { urban areas }\end{array}$ & $\begin{array}{l}\text { For body parts for } \\
\text { traditional medicine } \\
\text { / ceremonies }\end{array}$ & $\begin{array}{c}\text { Prestige of } \\
\text { hunting } \\
\text { /social status }\end{array}$ & Sport & Source \\
\hline Hunting concessions near Okavango, Botswana & 0 & 1 & 1 & 0 & 0 & 0 & K. Collins, unpublished data \\
\hline WAP complex, Benin, Burkina Faso, Niger & 0 & 1 & 1 & 1 & 0 & 0 & P Henschel unpublished data \\
\hline Comoé NP, Ivory coast & 1 & 0 & 1 & 1 & 0 & 0 & P Henschel unpublished data \\
\hline Batéké Plateau, SE Gabon & 1 & 1 & 1 & 0 & 0 & 0 & P Henschel unpublished data \\
\hline Sokoke Forest, Kenya & 1 & 1 & 0 & 0 & 0 & 0 & Fitzgibbon 2005 \\
\hline Gile Game Reserve, Mozambique & 1 & 1 & 1 & 0 & 0 & 0 & Fusari \& Carpaneto 2006 \\
\hline Coutada 9, Mozambique & 1 & 1 & 1 & 1 & 0 & 0 & Lindsey \& Bento 2012 \\
\hline Niassa Reserve, Mozambique & 1 & 1 & 0 & 1 & 0 & 0 & C. Begg, unpublished data \\
\hline Pafuri, RSA & 1 & 1 & 0 & 1 & 0 & 0 & C. Roche, unpublished data \\
\hline Various reserves, RSA & 1 & 1 & 0 & 0 & 0 & 1 & Warchol \& Johnson 2009 \\
\hline Private farms, Kwa-Zulu Natal, RSA & 1 & 0 & 0 & 0 & 0 & 1 & Grey-Ross et al. 2010 \\
\hline Ruaha ecosystem, Tanzania & 1 & 1 & 1 & 0 & 1 & 0 & A. Dickman, unpublished data \\
\hline Serengeti National Park, Tanzania & 1 & 1 & 1 & 1 & 1 & 0 & $\begin{array}{l}\text { Hofer 2000; Barnett 2002; Ndibalema \& Songorwa 2002; } \\
\text { Nyahongo et al. 2005; D. Loibooki et al. 2002; Rentsch } \\
\text { unpublished data }\end{array}$ \\
\hline North western Tanzania & 1 & 1 & 0 & 0 & 0 & 0 & Jambiya et al. 2007 \\
\hline Kafue National Park, Zambia & 1 & 1 & 1 & 0 & 0 & 0 & N. Midlane, unpublished data \\
\hline $\begin{array}{l}\text { North Luangwa National Park, Mukungule, Munyamadzi, and } \\
\text { W/E Musalangu game management areas }\end{array}$ & 1 & 1 & 1 & 1 & 1 & 1 & Van der Westhuizen, 2007 \\
\hline South Luangwa National Park, Upper and Lower Lupande, and & & & & 1 & & & D. Lewis, R. McRobb, M. Becker, unpublished data, (Becker et \\
\hline Sandwe game management areas, Zambia & 1 & 1 & 1 & & 1 & 0 & al., In press) \\
\hline Private conservancies, SE Zimbabwe & 1 & 1 & 0 & 1 & 0 & 0 & Lindsey et al. 2011 \\
\hline Gonarezhou National Park, Zimbabwe & 1 & 1 & 1 & 1 & 0 & 0 & H. van der Westhuizen unpublished data \\
\hline Average & 0.90 & 0.90 & 0.60 & 0.50 & 0.17 & 0.17 & \\
\hline
\end{tabular}


The price of bushmeat is related to distance from harvestable wildlife populations (Brashares et al., 2011), with prices relative to alternatives (livestock, poultry, and fish) significantly higher in urban (by $1.57 \pm 0.28$ times [mean \pm S.E.], $n=10$ published studies) than rural areas (where prices are $0.72 \pm 0.07$ those of alternatives, $n=19$ ) (Mann Whitney Test, $\mathrm{U}=21.0, \mathrm{p}<0.01$ ). Bushmeat transported $\geq 90 \mathrm{~km}$ from its source costs almost 50\% more than fish and chicken (Brashares et al., 2011). Correspondingly, hunters operating close to urban centres sell more of their catch than distant hunters (Brashares et al., 2011). Rural consumers typically select bushmeat over alternatives because it is cheaper or more available ( $78.5 \%$ of buyers, $n=12$ published studies), whereas urban consumers select it for its taste ( $100 \%$ of buyers, $\mathrm{n}=5$ sites) (Fisher's Exact Test, $p<0.01)$.

\section{Drivers of bushmeat hunting and trade}

\subsection{Increasing demand for bushmeat}

Human populations are growing faster in Africa than elsewhere, high population densities occur close to wildlife populations in some areas, urban populations in African cities are becoming wealthier and there are increasing African populations in international cities, resulting in elevated demand for bushmeat from multiple markets. Bushmeat comprises a small proportion of the protein consumed by urban societies (e.g. $2 \%$ in Gabon), but the large human populations involved mean that demand for the commodity is significant (Wilkie et al., 2011). There are significant inflows of bushmeat into Europe and the US, where it is sold for elevated prices (Chaber et al., 2010). Such demand is driving increased commercialization of trade, greater numbers of hunters, erosion of traditional hunting seasons and taboos (which meant that certain species were spared in some areas and that some cultures eschewed hunting), and the adoption of more effective hunting techniques, placing unprecedented pressure on wildlife populations (Barnett, 2000; Stiles, 2011). 


\subsection{Increasing human encroachment of wildlife areas}

Growing human populations are increasingly encroaching wildlife areas (Kiringe et al., 2007), driving elevated bushmeat hunting (Table 5). For example, various categories of protected areas in Ethiopia, Mozambique, Tanzania and Zambia are increasingly settled (Simasiku et al., 2008; Lindsey and Bento, 2012). Human population growth rates are high on the boundaries of protected areas and may even be higher in such areas than elsewhere (Wittemyer et al., 2008) (though that postulation is contested (Joppa et al., 2009)). In Zambia, for example, population growth rates in game management areas are higher than the mean in some cases (e.g. 4.1\% in Mambwe District, which encompasses two GMAs c.f. 2.8\% for Zambia as a whole) (Zambia Central Statistical Office, 2011).

Human encroachment can be greatly exacerbated by poorly planned infrastructure such as roads, clinics, schools and boreholes in or close to wildlife areas (van der Westhuizen, 2007; Dobson et al., 2010). Though well-intentioned, such developments tend to result in influxes of people into areas poorly suited to human settlement, creating dependency on exploitation of natural resources such as wildlife. In some cases, human influxes may be the result of failure of different government ministries to communicate effectively and plan in a coordinated fashion. For example, human encroachment has been worsened through efforts to control tsetse flies (Glossina spp.) which has enabled livestock-keeping and subsequent settlement in previously unfavourable areas (Muriuki et al., 2005). Similarly, encroachment of wildlife areas is exacerbated by forestry and mining, which increase the prevalence of bushmeat hunting due to road construction and human influxes (Clark et al., 2009; Poulsen et al., 2009). Logging companies often perceive bushmeat as a free commodity with which to supplement workers' income (Wilkie et al., 2011). The frequency of bushmeat hunting and rate of bushmeat consumption declines with distance from human settlements (Hofer et al., 
Table 5. Drivers for illegal hunting and the bushmeat trade in the savanna biome (NB that where information was extracted from literature, the lack of mention of some drivers does not necessarily mean those drivers are not in play in those areas)

\begin{tabular}{|c|c|c|c|c|c|c|c|c|c|}
\hline & $\begin{array}{l}\text { Inadequate } \\
\text { enforcement }\end{array}$ & $\begin{array}{l}\text { Money making } \\
\text { opportunity }\end{array}$ & $\begin{array}{l}\begin{array}{l}\text { Protein } \\
\text { shortages }\end{array} \\
\end{array}$ & $\begin{array}{l}\text { Poverty/lack of } \\
\text { alternative } \\
\text { livelihoods/ } \\
\text { employment }\end{array}$ & $\begin{array}{l}\text { Weak penal } \\
\text { systems }\end{array}$ & $\begin{array}{l}\text { Corrupt game } \\
\text { scouts/ } \\
\text { employees }\end{array}$ & $\begin{array}{l}\text { Human influxes } \\
\text { / population } \\
\text { increase }\end{array}$ & $\begin{array}{l}\text { Livestock held } \\
\text { as assets/lack } \\
\text { of livestock }\end{array}$ & $\begin{array}{l}\text { Lack of benefits } \\
\text { from wildlife }\end{array}$ \\
\hline Hunting concessions near Okavango, Botswana ${ }^{1}$ & 1 & 1 & 0 & 0 & 1 & 1 & 0 & 1 & 0 \\
\hline WAP complex, Benin, Burkina Faso, Niger ${ }^{2}$ & 1 & 1 & 0 & 0 & 1 & 1 & 0 & 0 & 0 \\
\hline Comoé NP, Ivory coast ${ }^{3}$ & 1 & 1 & 0 & 1 & 0 & 0 & 0 & 0 & 0 \\
\hline Batéké Plateau, SE Gabon ${ }^{3}$ & 1 & 1 & 1 & 1 & 0 & 0 & 0 & 0 & 0 \\
\hline Sokoke Forest, Kenya ${ }^{3}$ & 0 & 0 & 1 & 0 & 0 & 0 & 0 & 0 & 0 \\
\hline Protected areas in Kenya ${ }^{4}$ & 1 & 1 & 1 & 1 & 1 & 0 & 1 & 0 & 0 \\
\hline Gile Game Reserve, Mozambique ${ }^{5}$ & 1 & 1 & 1 & 1 & 0 & 0 & 1 & 0 & 0 \\
\hline 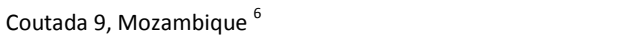 & 1 & 1 & 1 & 1 & 1 & 1 & 1 & 1 & 1 \\
\hline Niassa Reserve. Mozambique & 1 & 1 & 1 & 1 & 1 & 1 & 1 & 1 & 1 \\
\hline Pafuri, RSA $^{7}$ & 1 & 1 & 1 & 1 & 1 & 0 & 0 & 1 & 0 \\
\hline Various reserves, $\mathrm{RSA}^{8}$ & 1 & 1 & 1 & 1 & 1 & 1 & 0 & 1 & 1 \\
\hline Private farms, Kwa-Zulu Natal, RSA ${ }^{9}$ & 1 & 0 & 1 & 1 & 1 & 1 & 0 & 0 & 0 \\
\hline Kilombero, Tanzania ${ }^{10}$ & 1 & 0 & 0 & 0 & 0 & 0 & 0 & 0 & 1 \\
\hline Ruaha ecosystem, Tanzania ${ }^{11}$ & 1 & 1 & 1 & 1 & 1 & 1 & 1 & 0 & 1 \\
\hline Serengeti National Park, Tanzania ${ }^{12}$ & 1 & 1 & 1 & 1 & 1 & 1 & 1 & 1 & 1 \\
\hline North western Tanzania ${ }^{13}$ & 1 & 1 & 1 & 1 & 1 & 0 & 1 & 0 & 0 \\
\hline Kafue National Park, Zambia ${ }^{14}$ & 1 & 1 & 1 & 1 & 1 & 1 & 1 & 1 & 1 \\
\hline $\begin{array}{l}\text { North Luangwa NP, Mukungule, Munyamadzi, and W/E } \\
\text { Musalangu game management areas } \\
\text { South Luangwa National Park, Upper and Lower Lupande, and }\end{array}$ & 0 & 1 & 1 & 1 & 0 & 0 & 0 & 0 & 1 \\
\hline Sandwe game management areas, Zambia ${ }^{16}$ & 1 & 1 & 1 & 1 & 1 & 0 & 1 & 1 & 1 \\
\hline Savé Valley Conservancy, Zimbabwe ${ }^{17}$ & 1 & 1 & 1 & 1 & 1 & 1 & 1 & 1 & 1 \\
\hline Gonarezhou National Park, Zimbabwe ${ }^{18}$ & 1 & 1 & 1 & 1 & 1 & 1 & 1 & 1 & 1 \\
\hline Average & 0.90 & 0.86 & 0.81 & 0.81 & 0.71 & 0.52 & 0.52 & 0.48 & 0.52 \\
\hline
\end{tabular}


1996; Muchaal and Ngandjui, 1999; Brashares et al., 2011; Lindsey et al., 2011a) and wildlife populations fare better where human settlement is not permitted (Stoner et al., 2007).

\subsection{Poverty and food insecurity}

Rural African communities suffer high levels of unemployment and poverty (Brown, 2007), and the quick income possible from selling meat is a common incentive for bushmeat hunting (Table 5). Individuals with part-time or seasonal employment allocate more time to hunting than those with full-time jobs (Brashares et al., 2011). Lands where wildlife persists are frequently poorly suited to agriculture and food shortages prevail. Reliance on bushmeat is created by shortages of alternative proteins and carbohydrates (as meat is often traded for grain (Lindsey et al., 2011b)) (Table 5). Demand for bushmeat is exacerbated in some areas by diseases such as trypanosomiasis and Newcastle's disease which preclude or reduce livestock production (Lewis, 2005). Furthermore, communities often retain livestock as assets and use bushmeat for daily protein needs (Barnett, 2000). Consequently, bushmeat contributes significantly to food security in many areas (Nyahongo et al., 2005). Around the Serengeti, bushmeat comprises $31 \%$ of meat consumed (D. Rentsch, unpublished data). However, declining wildlife populations in many areas mean that the contribution of bushmeat to food security will wane without interventions to make harvests sustainable.

\subsection{Lack of clear rights over wildlife or land}

In many countries, communities lack rights over their land or the wildlife that they live with, meaning that bushmeat hunting is the only way they can access benefits from wildlife. In some places, efforts have been made to remedy this situation via devolution of user-rights over wildlife to communities and development of community-based natural resource management (CBNRM) 
programmes. However, in most cases (e.g. Botswana, Tanzania, Zambia and Zimbabwe), governments retain significant proportions of revenue from wildlife and incentives for conservation are weak (Suich et al., 2009). Marginalizing local people from benefits of wildlife can create strained relations with the wildlife sector, which are often worsened by human-wildlife conflict, heavyhanded anti-poaching and historical grievances over land. In such instances, bushmeat hunting may be a form of protest (Holmes, 2007).

\section{Contributing factors that facilitate the bushmeat trade}

\subsection{Inadequate legal protection for wildlife, law enforcement or penal systems}

In many countries, gazetted punishments for bushmeat hunting are inadequate and do not reflect the value of wildlife (Barnett, 2000). Penalties typically comprise warnings, community service or fines of lower value than the meat obtained from bushmeat hunting (Barnett, 2000), and in many cases, bushmeat hunters are not convicted at all. For example, 60 hunters were arrested in the NG26 concession in Botswana from 2010-2012, but none were convicted (K. Collins, pers. comm.). Due to poor record-keeping, magistrates often fail to consider the criminal history of bushmeat hunters, so first-time and repeat offenders receive similarly weak punishments (V. Opyene, unpublished data). Wildlife laws are not harmonized among neighbouring countries, which can create loopholes and encourage cross-border poaching (V. Opyene, unpublished data). Wildlife offences are typically granted much lower priority than those involving livestock, despite the fact that the wild animals killed often have a much higher value, prejudicing the development of wildlife-based land uses (Lindsey et al., 2011a).

Many governments lack the will, and most state wildlife agencies lack the necessary resources or expertise to enforce laws effectively (Manousrian and Dudley, 2008) (Table 5). The Zambia Wildlife 
Authority (ZAWA), for example, has a force of 1,179 scouts to protect a wildlife estate of $\sim 233,000$ $\mathrm{km}^{2}$ (ZAWA, pers. comm.). Consequently, the risk of bushmeat hunters being caught is low in many places. In the Serengeti, for example, $<1 \%$ of illegal hunters are apprehended (Loibooki et al., 2002). In some cases, protected areas are simply overwhelmed by the scale of the threat; for example, $\sim 9,600$ poachers were arrested in two months following establishment of refugee camps in Tanzania in the mid-1990s, 7,480 of whom escaped from custody (Jambiya et al., 2007).

The efficacy of anti-poaching is often undermined by poor morale resulting from low salaries, corruption, and lack of equipment and supervision (Lindsey et al., 2011a). Scouts are sometimes bribed by bushmeat hunters to turn a blind-eye, and scouts themselves sometimes poach (Lindsey et al., 2011a). In Mozambique, police and local government officials (those responsible for penalizing bushmeat hunters) often buy bushmeat (Lindsey and Bento, 2012) and in Central Africa, government officials sometimes pay poachers to hunt elephants for ivory, who then accrue the meat for sale (Stiles, 2011).

\subsection{Political instability}

Bushmeat hunting typically increases during periods of political instability due to a breakdown in law enforcement and reduced availability of alternative food. This was observed on wildlife ranches in Zimbabwe during land 'reform', in North West Tanzania following the establishment of refugee camps, and in Mozambique, Democratic Republic of Congo and Central African Republic during periods of armed conflict (de Merode et al., 2007; Bouché et al., 2012). 


\subsection{Demand for wildlife body parts for traditional use}

Wildlife body-parts are often used for traditional medicines and cultural practises, and the sale of such items can increase the profitability of bushmeat hunting. For example, the skins of spotted carnivores such as leopards (Panthera pardus) and genets (Genetta spp.) fetch high prices (e.g. US\$83-\$2,500 for leopard skins in Mozambique, C. Begg, unpublished data). In addition expanded trade of wildlife parts such as the recent practice of selling lion (Panthera leo) as tiger (Panthera tigris) bones in Asian markets is an indication that such trade may increase in future (Lindsey et al., 2012).

\subsection{Abundant material for making snares}

Controlling bushmeat hunting is made difficult in some areas due the abundance of wire which is used to make snares. In Zambia, the electricity supply corporation has increased wire availability in rural areas during expansion of the national grid, particularly in areas with expanding wildlife-based tourism economies (Becker et al., 2012). In Savé Valley Conservancy, most of the $>84,000$ snares removed during 2002-2009 were made from wire from the perimeter fence (Lindsey et al., 2012). Where wire is scarce, illegal hunters are forced to use materials (e.g. gin traps) that are easier to control and harder to replace (Lindsey and Bento, 2012).

\section{Potential solutions and associated challenges}

\subsection{Land use planning}

Creating distance or minimizing the interface between people and wildlife is a key means of reducing bushmeat hunting (Lindsey et al., 2011a). Developing and maintaining large protected areas is 
essential as there is a positive relationship between reserve size and retention of wildlife diversity (Newmark, 2008). Effective reserve size can be increased in some cases by creating transfrontier protected areas (Newmark, 2008). Gazetting semi-protected areas and promoting of wildlife-based land uses adjacent to reserves can create buffers, help conserve critical habitats and reduce edgeeffects (Stokes et al., 2010). Where human settlement in reserves is prohibited, enforcing such prohibitions is crucial. Furthermore, human movement through and within parks should be controlled, as livestock grazing and resource collection are used as covers for bushmeat hunting (Lindsey and Bento, 2012; H. van der Westhuizen unpublished data). Where human settlement in reserves is permitted/tolerated, land zoning can help reconcile conservation and human needs (Naughton-Treves et al., 2005). Zoning can help protect wildlife areas and encourage agencies to focus human development initiatives in defined settlement and agricultural areas. Zoning has been implemented in Coutada 9 in Mozambique, resulting in reduced bushmeat hunting and recovering wildlife populations (Lindsey and Bento, 2012).

Fencing can assist land-use planning, limit edge-effects in habitat fragments and reduce bushmeat hunting by reducing wildlife movement from and human incursion into reserves (Lindsey et al., 2012). Fences demarcate reserves and emphasize the illegality of entering and hunting therein (Hayward, 2009). Fences can also assist anti-poaching as the cleared ground maintained within fence lines enables detection of human incursion (Lindsey et al., 2012). Fences can also sometimes reduce human-wildlife conflicts, thereby improving relations between the wildlife-sector and adjacent communities (Lindsey et al., 2012).

Careful positioning of infrastructure development can discourage human influxes into wildlife areas. Similarly, other land uses that occur within wildlife areas require careful management. When allocating forestry rights, for example, governments should ensure that concessions are large and contain patches of unlogged forest (Clark et al., 2009). Care is required to prevent an unregulated 
influx of people to forestry and mining concessions, restrict movement within wildlife areas and ensure that workers are supplied with protein (Poulsen et al., 2009). Mining and forestry companies should also be encouraged to actively protect wildlife populations as part of their corporate responsibility. The De Beers mining company, for example, actively protects wildlife across 2,300 $\mathrm{km}^{2}$ of concessions (http://www.debeersgroup.com/Sustainability/Environment/Biodiversity/, accessed November 2012). Finally, care is required with refugee camp establishment, to ensure that they are not located near wildlife areas and to ensure that adequate meat protein is provided (Jambiya et al., 2007).

\subsubsection{Challenges associated with land-use planning}

Effective land use planning is likely to require cross-ministerial communication and cooperation. Such cooperation is likely to require significant efforts to raise awareness among ministries of the ecological impacts associated with human encroachment in wildlife areas. Zoning is costly, time consuming and only effective with local support (Naughton-Treves et al., 2005). Where wildlife or people are dependent on seasonal migration to exploit natural resources, zoning is of limited applicability (Goldman, 2003). Convincing governments to consider issues such as bushmeat hunting will be challenging when they are implementing land uses as profitable as mining and forestry. Finally, fences are costly to erect and maintain, can impose ecological impacts by blocking seasonal movements of wildlife and can create massive supplies of snare-wire if designed poorly (Lindsey et al., 2011a; Hayward, 2012).

\subsection{Promoting development of alternative livelihoods}

Providing alternative income options is vital for reducing reliance of communities on bushmeat. To this end, integrated conservation and development projects (ICDPs) have been established around 
several reserves (Naughton-Treves et al., 2005). ICDPs are designed to promote sustainable development options (e.g. ecotourism, agro-forestry and sustainable harvest of biological resources) compatible with conservation objectives (Naughton-Treves et al., 2005). Several small-scale projects have been attempted close to wildlife areas, such as honey production, crafts production, nurseries, and food-crop production (Van Vliet, 2011). Agricultural projects have particular potential given the relationship between bushmeat hunting/consumption and food insecurity. In Zambia, the Community Markets for Conservation project aims to improve farming skills adjacent to wildlife areas and reward conservation-compliant communities with elevated prices for their produce, and is succeeding at reducing bushmeat hunting (Lewis et al. 2011).

\subsection{Providing alternative protein and carbohydrate supplies}

Several options exist for reducing reliance on bushmeat for food. a) Protecting/increasing fish supplies. Fish represents a direct replacement for bushmeat in some areas (Wilkie et al., 2005). In Ghana, for example, bushmeat hunting consumption is negatively correlated with fish supplies (Brashares et al., 2004). Fish supplies per person in Africa declined by $14 \%$ during $1984-2000$ (Ronnback et al., 2002), and improved management of fish stocks is necessary to help reduce demand for illegal bushmeat. Fresh-water and coastal aquaculture has potential to supply fish, molluscs, crustaceans and seaweed and reduce demand for wild fish and bushmeat (Ronnback et al., 2002). b) Addressing veterinary diseases and promoting poultry production. For example, vaccinating chickens against Newcastle disease (coupled with improved husbandry) can increase poultry production by 3-4 times (Lewis, 2005). c) Farming of indigenous mammals such as cane rats (Thryonomys spp.) can potentially generate sustainable supplies of bushmeat (Jori 1995). d) Legal production of game meat has significant potential and is discussed in more detail below. 
Ensuring that availability of grain foods are sufficient for the entire year is also essential, to prevent reliance on the sale of bushmeat to generate cash to buy grain. The effectiveness of alternative protein approaches may be improved by interventions to increase the price and/or reduce the supply of illegal bushmeat such as by imposing controls on transport of the product, increasing antipoaching, and providing hunters with alternative livelihoods.

\subsubsection{Challenges with solutions based on alternative livelihoods and proteins}

There is little information on the success of alternative livelihood or protein projects on bushmeat hunting (Van Vliet, 2011). ICDPs have been criticized for failing to improve livelihoods or confer conservation gains (Naughton-Treves et al., 2005). Where development projects are successful, there is a risk of local population influxes (Wittemyer et al., 2008). There is no guarantee that alternative income or protein options would reduce bushmeat hunting. Hunting and selling bushmeat yields quick profits, confers elevated social status, is usually low risk and requires relatively little time or capital: characteristics often not true of alternative livelihood options (Van Vliet, 2011). Promoting the preferential use of alternative proteins will be challenging where bushmeat prices are low, such as near wildlife areas. There is no guarantee that the income/protein will not be used to augment that from bushmeat, or that other individuals would not take the place of 'reformed' hunters. Such augmentation may be discouraged by including conditional clauses in alternative livelihood/protein projects whereby participation is contingent on the community involved desisting from hunting (Van Vliet, 2011) and by combining such approaches with law enforcement.

There is a risk that increased wealth will increase demand for bushmeat. Relationships between wealth, livestock ownership and bushmeat consumption are complex and variable (Wilkie et al., 2005; Wilkie et al., 2011; Foerster et al., 2012). In Gabon and Equatorial Guinea, bushmeat 
consumption increases with income (East et al., 2005; Wilkie et al., 2005; Fa et al., 2009). In the Serengeti, livestock ownership is a poor predictor of bushmeat use, and a chicken vaccination programme increased household cash income and bushmeat usage (D. Rentsch unpublished data). By contrast, on Bioko island in Equatorial Guinea, bushmeat consumption declined with increasing income, as costlier proteins were selected (Albrechtsen et al., 2005; Fa et al., 2009). In western Tanzania, as income from agriculture and livestock increases, the frequency of bushmeat hunting declines (Wilfred and MacColl, 2010). Generally, in rural areas the poorest households consume the most bushmeat, whereas in urban settings wealthier households consume more (Brashares et al., 2011). This finding stresses the importance of alternative income approaches targeting poor households in communities adjacent to protected areas.

Meat from domestic sources may not be considered acceptable replacements for bushmeat by some communities, due to cultural preferences (Van Vliet, 2011) and demand for the product is unlikely to disappear regardless of the availability of alternative proteins. Consequently providing legislative and policy frameworks to allow communities to access meat and other benefits from wildlife in a legal and sustainable way are important.

There are potentially significant negative environmental externalities associated with improved livestock production and aquaculture, though such impacts can be reduced through proper management (Ronnback et al., 2002). Aquaculture and indigenous species farming requires significant start-up capital and expertise, and can create reliance on protracted donor support. Farming of indigenous species has had limited success as hunting is often easier, productivity sometimes suffers from disease outbreaks; and the necessary legal and policy frameworks, markets, and extension services are lacking (Van Vliet, 2011).

As a result of these challenges, alternative livelihoods and protein supplies are unlikely to be effective at reducing bushmeat hunting in isolation, and must be combined with other interventions such as enforcement and legal bases for communities to benefit from wildlife. 


\subsection{Developing formal wildlife-based land uses}

Bushmeat hunting is an inefficient form of wildlife-use due to wastage, lack of selectivity of the gender and age of animals killed, failure to capture the tourism or trophy values of the animals killed, and low prices often obtained for bushmeat. In Zimbabwe, bushmeat hunters capture $<1 \%$ of the value of the wildlife they destroy (Lindsey et al., 2011a). Efficient, regulated and selective wildlife harvesting can potentially produce significant quantities of meat sustainably. Legal harvest can yield a fresher, more hygienic product, of guaranteed and preferred species-origin, with lower risks of zoonoses (Lindsey et al., 2011a; Alexander et al., 2012). Legal wildlife-based land uses can generate income from trophy hunting, ecotourism and the sale of by-products such as skins, which is why wildlife-ranching has replaced (or complements) livestock production across large areas of private land in semi-arid southern Africa (Bond et al. 2004). Wildlife-based land uses could be used to address bushmeat hunting and trade in the following contexts:

\subsubsection{Wildlife-ranching on private land}

In several southern African countries, user-rights over wildlife were devolved to private land owners during the 1960-70s, resulting in the rapid spread of wildlife-ranching (Bond et al., 2004). Wildliferanching is practised across $\sim 287,000 \mathrm{~km}^{2}$ in Namibia, $200,000 \mathrm{~km}^{2}$ in South Africa and $27,000 \mathrm{~km}^{2}$ in Zimbabwe (pre- land reform), with smaller (but expanding) areas in Botswana, Zambia and Mozambique (Bond et al., 2004; Lindsey et al., In press). In Namibia, 16,000-26,000 tonnes of game meat are produced annually on wildlife ranches (Lindsey et al., In press), and 2.4 million tonnes were produced annually in Zimbabwe prior to the land seizures (Le Bel et al., 2004). In South Africa, game meat may comprise $10 \%$ of total meat consumption during the hunting season (Dry 2010). These meat harvests have been achieved sustainably and wildlife populations on private land in Namibia, South Africa and Zimbabwe (pre-land reform) have increased dramatically (Bond et al., 2004). In 
countries with little private land, governments could encourage wildlife-ranching on state land by allocating long leases to private investors and/or communities.

In southern Africa, wildlife ranches could potentially reduce demand for bushmeat both in urban and rural areas if ranched meat is channelled appropriately. There is scope for the export of game meat from countries with large legal supplies (e.g. South Africa, Namibia) to countries with high demand and low legal supplies (e.g. Zambia, Mozambique, Tanzania). Concurrent with efforts to promote legal game meat production, there is a need to streamline procedures for transporting legal game meat (while addressing the potential for disease transmission), and to impose tighter controls on transporting illegal bushmeat.

\subsubsection{Wildlife-based land uses on communal land}

Significant potential exists for developing wildlife-based land uses and producing game meat on communal lands if governments devolve user-rights over wildlife to communities adequately, to provide incentives for the conservation of the resource. The most successful CBNRM programme is the communal conservancy programme in Namibia, where a combination of relatively complete devolution of wildlife user-rights, adequate technical and funding support, and low human densities have resulted in strong incentives for sustainable use of wildlife, sharp reductions in bushmeat hunting, the development of 76 communal conservancies covering $\sim 155,000 \mathrm{~km}^{2}$, and recovering wildlife populations (http://www.nacso.org.na/SOC_profiles/Namibia's\%20Communal\%20Conservancies.pdf, accessed June 2012). Tourism and trophy hunting in Namibian communal conservancies currently generate US\$26.4 million, 2,850 jobs and 315,000 kg of game meat annually (significant quantities accruing to households: e.g. 120 kg/household/year in Nyae Nyae) (R. Diggle unpublished data). Similarly, in 
Ankasa in Ghana, the devolution of user-rights over wildlife to communities has resulted in reduced bushmeat hunting and increasing wildlife populations (M. Murphree unpublished data).

In some cases alternative models of developing wildlife-based land uses on communal land may be appropriate. One option is for the development of wildlife ranches in communal areas through establishment of private-community partnerships. If established correctly, such arrangements could provide the capital necessary to re-stock wildlife (if necessary) and develop infrastructure required for hunting or photo-tourism (and/or meat harvesting), while creating scope for ongoing benefits for communities and incentives for desisting from bushmeat hunting. Scope exists for such arrangements where there are blocks of wilderness remaining in areas partially occupied by communities, such as the Zambian Game Management Areas, Mozambican hunting Coutadas, or Tanzanian Open/Game Controlled Areas (Lindsey, unpublished data).

Finally, in some community areas (including Guruve in Zimbabwe, and adjacent to Serengeti NP), legal wildlife-cropping has been attempted in order to replace bushmeat with a regulated harvest, though these initiatives all failed (Feron, 1995; Holmern et al., 2002; Le Bel et al., 2004).

\subsubsection{Extending benefits from protected areas to communities}

Extending the benefits from protected areas to neighbouring communities can create disincentives for bushmeat hunting. Various possibilities exist, including: employment; allocating portions of park earnings; involving communities in park management; environmental education; purchasing of produce for tourism from communities; cultural tourism; and allocating stake-holdings (or even complete ownership) of conservation areas to communities (Grossman \& Holden 2008). For example, in Namibia, communities are granted concessions in state reserves which they can use to attract tourism opportunities (Weaver, 2011). Ownership of state/private protected areas could be 
converted into shareholdings available for purchase by communities (perhaps with donor support) and private companies, thus developing public-private-community partnerships. Such models are business-like and create linkages between park-performance and income for communities, thus creating disincentives for bushmeat hunting.

\subsubsection{Challenges associated with developing legal wildlife-based land uses}

Pressure from Western protectionist and animal welfare organisations for restrictions on the sustainable use of wildlife and on the international movement of hunting trophies poses a threat to wildlife-based land uses (Norton-Griffiths 2007). Maximizing the financial value of wildlife through legal forms of utilization is an essential to allow wildlife-based and uses to compete with alternatives and international restrictions on the imports of hunting trophies should be avoided (Lindsey et al. 2012).

Internal policy and legislative constraints also limit the development of wildlife-based land uses in several countries, perhaps most notably a failure of governments to devolve user rights adequately to private landowners and/or communities and a tendency to introduce bureaucratic barriers to the use of wildlife and/or legal sale of wildlife products (Child 2009; Lindsey et al. in press). Challenges associated with replacing illegal bushmeat with legally sourced game meat include the difficulty of achieving competitive pricing and overcoming veterinary restrictions on the movement of wildlife products in many countries. There is a need for altered marketing strategies by game ranchers to ensure that game meat produced is distributed to the areas where demand for bushmeat is highest. Finally, there is a risk that illegal bushmeat could be laundered and sold as legal game meat, and some kind of certification system may be required. Another barrier to the development of wildlifebased land uses is the misconception, particularly among politicians, that they threaten food security (du Toit, 2004). 
There are a number of challenges are specifically associated with CBNRM, including; the need for protracted technical and donor input; difficulty associated with defining communities; and limited returns per household in areas with high human population densities (Jones, 2007). Wildlife harvesting programmes in communal areas have faced a number of challenges, including: low financial viability; elite capture of benefits; high start-up costs; failure to generate comparable quantities of meat to that produced from bushmeat hunting; failure to capture other value streams from wildlife; uncertainty over appropriate recipients of meat and income; veterinary restrictions on meat distribution; competing claims for shared resources; erratic meat supplies and the low purchasing power of local communities (Parker, 1986; Balakrishnan and Ndhlovu, 1992; Féron et al., 1998; Holmern et al., 2002; Le Bel et al., 2004). Combinations of these factors have led to the dissolution of operations described by Feron et al. (1998) and Le Bel et al. (2004). Wildlife cropping is only likely to be viable as part of CBNRM programmes which aim to capture multiple-use values from wildlife.

\subsection{Payments to encourage coexistence}

Payments to promote coexistence with wildlife and to encourage communities to desist from hunting illegally represent an additional option to address the bushmeat trade. Such payments can help overcome the mismatch between external groups who capture the actual and existence values of wildlife and the local people who bear the costs associated with living with it. Diverse income streams (e.g. from legal wildlife-use and external financing) could be combined into payments to encourage coexistence, to be allocated if conservation objectives are achieved (e.g. reduced bushmeat hunting or recovering wildlife populations) and to help compensate for wildlife damages (Dickman et al., 2011). This approach would link conservation investment directly to actual conservation success and help reduce poverty and food insecurity (Groom and Palmer, 2010). This 
kind of economic approach can attract more funding than traditional conservation from a wider range of donors (Goldman et al., 2008).

\subsubsection{Challenges associated with payments for coexistence}

A key challenge would be securing long-term, reliable funding, as markets for biodiversity off-sets have not yet been fully developed. Once a payment scheme is established, stopping it could cause elevated antagonism towards wildlife (Montag, 2003). Other challenges include: identifying reliable indicators of success; dealing with fluctuating environmental conditions; determining who should receive payments (in a manner agreeable to the whole community) and ensuring that payments are transparent, equitable and sufficient to offset the costs of wildlife presence; and, avoiding corruption and elite capture of funds (Dickman et al., 2011).

\subsection{Adequate legal protection and law enforcement}

While 'fortress conservation' has rightly been eschewed in favour of approaches that combine conservation and local development, wildlife laws are often not complied with voluntarily (Rowcliffe et al., 2004) so enforcement through anti-poaching and measures to control bushmeat transport and sale is essential. The need for enforcement is acknowledged in the Lusaka Agreement (http://www.lusakaagreement.org/Documents/3.5.pdf, accessed May 2012), the African Convention on the Conservation of Nature and Natural Resources (http://www.africaunion.org/root/au/Documents/Treaties/Text/nature\%20and\%20natural\%20recesource.pdf, accessed May 2012) and the SADC (southern African Development Community) Protocol on Law Enforcement and Wildlife Conservation (SADC Protocol on Law Enforcement and Wildlife Conservation, accessed November 2012). By increasing the costs associated with bushmeat hunting, effective enforcement can increase the likelihood of alternative livelihood-type interventions 
working. Governments (and NGO partners) can improve law enforcement in various ways. In the short term, the most important step is to improve the level of investment in and quality of management associated with anti-poaching.

\subsubsection{Improved anti-poaching security}

There is abundant evidence that elevated anti-poaching security can be effective at reducing bushmeat hunting (Hilborn et al., 2006; van der Westhuizen, 2007; Jachmann, 2008a; Stokes et al., 2010) and compelling evidence that stiff punishments for bushmeat hunting are ineffective if the risks of being caught are low (Leader-Williams and Milner-Gulland, 1993; Hofer et al., 2000). Bushmeat hunting is generally less well addressed than other threats in protected areas (Bruner et al., 2001) and greatly elevated investment in anti-poaching is needed in many reserves (Scholte, 2011). There are several key steps that can be taken by governments to improve enforcement:

a) Allocation of adequate funding. In Ghana, snaring was effectively controlled in six savanna parks with an enforcement budget of US\$51/ $\mathrm{km}^{2} /$ year (Jachmann, 2008a). In the $3,872 \mathrm{~km}^{2}$ Coutada 9 in Mozambique, an expenditure of US\$28.4/ $\mathrm{km}^{2}$ on anti-poaching has been sufficient to enable wildlife populations to start recovering following historical illegal harvest (Lindsey and Bento, 2012). In the $3,500 \mathrm{~km}^{2}$ Save Valley Conservancy, a security budget of US\$72/ $\mathrm{km}^{2}$ was sufficient to prevent wildlife population declines everywhere but the highest-pressure areas close to areas settled during the recent land seizures (Lindsey et al., 2012).

b) Adequate manpower to enable sufficient patrol days per month. The manpower and funding needed to control illegal hunting is likely to vary with: the degree of threat from illegal hunting; terrain; vegetation; the size and shape (surface area:volume) of the wildlife area; and, the presence/absence of rhinoceroses (which are a key target for trophy poachers) (van der Westhuizen, 2007; Jachmann, 2008a). 
c) Strategic deployment of scouts to cater for temporal and spatial patterns of bushmeat hunting and prevent hunters from predicting timing and location of patrols (Jachmann, 2008a).

d) Employment of experienced staff, qualified for all anti-poaching tasks, and ongoing training programmes to maintain and improve their skills. In addition, there is a need for wildlife agencies to take measures to avoid being burdened by high proportions of inadequately skilled, unfit or sick employees.

e) Adequate working conditions, salaries and equipment (taking into account the strenuous and dangerous nature of the work), to maintain morale, prevent high rates of staff turnover and reduce the likelihood of collusion between scouts and hunters (Jachmann and Billiouw, 1997; Lindsey et al., 2011a). Essential equipment for scouts includes uniforms, hats, boots, radios, handcuffs, GPS units, and firearms.

f) Timely payment of sufficient bonuses for arrests or confiscation of weapons (Jachmann and Billiouw, 1997).

g) Adequate management and supervision of anti-poaching scouts, to maintain morale, reduce corrupt practises among scouts and ensure optimal allocation of effort (Jachmann, 2008a). In Ghanaian parks, visits of scout camps by senior staff members increased the effectiveness of antipoaching patrol teams (Jachmann, 2008a).

h) Intelligence gathering on planned activities of bushmeat hunters, as this can dramatically improve the effectiveness of anti-poaching (Martin, 1996). Such information can be gathered by employing appropriately connected individuals and/or by paying informants within nearby communities.

i) Developing a good working relationship with the police and local magistrates to ensure effective processing of detainees following apprehension.

j) Adequate monitoring of law enforcement efforts to allow for adaptive deployment of resources and assessment of the performance of staff (discussed in more depth below). 


\subsubsection{Reform of wildlife laws}

An additional step needed over the longer term is to reform wildlife laws to achieve greater uniformity among neighbouring countries and provide stronger deterrents. Databases of bushmeat hunters are needed to enable identification of repeat offenders. Efforts are needed to raise awareness among the judiciary and law enforcement agencies of the value of wildlife and the threat posed by bushmeat hunting. Such efforts were made by the Uganda Wildlife Authority and achieved a shift from minor penalties for bushmeat hunting (small fines [ US\$10-20] or community service) to custodial sentences of 6-12 months for first-time offenders (V. Opyene pers. comm.).

\subsubsection{Challenges associated with law enforcement}

Communities who rely most on bushmeat are often also the poorest and most food insecure, so efforts to enforce wildlife laws should be combined with efforts to provide alternative livelihoods (Brashares et al., 2011). Anti-poaching is expensive and specialized, and can create animosity with local communities if not handled sensitively and not coupled with efforts to extend benefits from wildlife to communities (Keane et al., 2008).

\subsection{Reducing availability of snare wire}

Reducing the availability of wire is essential to help control snaring. This can be achieved by securing wire stocks and by using alternative materials for fences. Fencing constructed from barbed or steel wire can be readily converted to snares, whereas that made with kinked, mesh (bonnox/veldspan ${ }^{\mathrm{TM}}$ ) fencing cannot (Lindsey et al., 2012). It is important to raise awareness among governments, businesses and landowners about the negative environmental impacts of wire, which wire-types are less amenable to use in snares, and the need to secure wire to reduce theft by hunters. 


\section{Monitoring the effectiveness of interventions}

Monitoring of illegal hunting and the bushmeat trade can provide insights into the effectiveness of interventions. The event-book system is a simple method for monitoring the incidence of illegal hunting that is easily applied and interpreted by anti-poaching scouts and not reliant on high-levels of training or education (Stuart-Hill et al., 2005). Alternatively, higher-tech monitoring systems such as the Management Information System or Spatial Monitoring and Reporting Tool programmes offer scope for monitoring the nature and extent of illegal hunting (corrected for anti-poaching effort), evaluating the efficacy of law enforcement and assessing the personnel performance. Such tools allow adaptive management of law enforcement in line with temporal and spatial trends in the threat. In Ghanaian parks, evaluation of the effectiveness of anti-poaching patrol teams created a spirit of competition among parks which improved performance (Jachmann, 2008b). Finally, monitoring of the bushmeat trade, via assessment of indices such as catch-per-unit-effort of hunters or species compositions in bushmeat markets can provide insights into the impacts of off-takes (Fa et al., 2000; Rist et al., 2010).

\section{Funding the necessary interventions}

Necessary interventions will require substantial funding. Providing adequate performance-based funding for state wildlife agencies represents an essential step, as declining budgets severely undermine their ability to protect wildlife (Cumming, 2004). For example, ZAWA operates with a budget of $<20 \%$ of that needed to function effectively, and consequently their mandate of protecting the vast wildlife estate is impossible to fulfil (World Bank, 2012).

Maximizing the economic value of wildlife is important to generate funds for wildlife management and restrictions on legal sustainable use are unadvisable (Lindsey et al., 2012). Where state land is 
leased to tourism and hunting operators, long-term leases should be allocated to incentivize investment in anti-poaching (Lindsey et al., 2007). Funding for reserves could be generated by developing the shareholding structures discussed earlier and encouraging external investment, or by seeking co-management arrangements with NGOs or the private sector. Co-management agreements have potentially to significantly bolster the funding and capacity available to manage protected areas and have achieved some notable successes at reducing illegal bushmeat harvests (e.g. North Luangwa, Lower Zambezi and Liuwa Plains national parks in Zambia and Gonarezhou National Park in Zimbabwe) (Child et al., 2004). Finally, the potential for generating funding for protected area management via markets for carbon off-sets and biodiversity credits should be pursued.

There is a need to raise awareness amongst the international community of the threat posed by bushmeat hunting, to leverage more funding to address the problem. Because of the obvious links between bushmeat and food security, gaining funding from development and humanitarian agencies is a realistic possibility (Lindsey et al., 2011a; Lindsey et al., 2011b); however attention must be paid to evidence of repeated failures of development aid (Moyo, 2009).

\section{Differences between savanna and forest biomes}

Key differences exist between forest and savanna biomes with regard to bushmeat hunting and potential solutions. Bushmeat hunting is easier and cheaper to control in savannas (Jachmann, 2008a). There are better established and larger tourism and trophy hunting industries in many savanna countries (Wilkie and Carpenter, 1999), so there is likely to be stronger political recognition of the value of wildlife, and greater wildlife-management and scientific capacity. Frameworks necessary to enable land owners and communities to benefit legally from wildlife are better developed in some southern African countries (Bond et al., 2004). Savannas are more productive 
than forests, and so wildlife-based land uses are more likely to be viable (Robinson and Bennett, 2004). Savannas can also support higher densities of livestock, so communities need not necessarily rely on bushmeat for protein (H. Eves, personal communication).

In the literature on bushmeat in forests, the idea is often espoused that bushmeat hunting should be accepted, but regulated (Muchaal and Ngandjui, 1999; Wilkie et al., 2005; Mockrin et al., 2011). In savannas, however, accepting wasteful, inefficient utilization of wildlife via illegal bushmeat hunting is not advisable or likely to be politically acceptable. Rather, the legal and sustainable utilization of wildlife should be pursued in a manner that confers maximal benefits to communities, in conjunction with other the interventions highlighted.

\section{Research needs}

There is an urgent need for more research on bushmeat hunting and trade in the savanna biomes. Lack of available data makes it difficult to assess the extent of the threat relative to other issues, to determine whether (as suspected) the threat is increasing in scope, or to identify how the threat varies in time and space. This lack of information undermines efforts to mobilize governments to develop coordinated, inter-ministerial responses to address the issue, or to encourage greater focus and investment from NGOs. Research is urgently needed to assess the scale, distribution, trends and patterns associated with bushmeat hunting and trade, and to quantify the ecological, economic and social impacts. In addition, an assessment of the role played by bushmeat in meeting food security needs is needed. Finally, there is a need to assess the scale of potential meat and financial benefits that could be generated from legal wildlife-based land uses in areas where they do not currently occur (or succeed), and to identify the legislative, policy and marketing frameworks necessary for them to arise and work. 


\section{Conclusions}

Bushmeat hunting is a severe threat to wildlife in savannas. The drivers of bushmeat hunting are complex and varied, so multiple interventions will often be required, with the suite of appropriate solutions varying between sites. Failure to address the problem will have dire consequences for wildlife in savanna ecosystems. Economic impacts will include the loss of potentially significant revenues from tourism and legal wildlife-based land uses. Social impacts will be felt through the loss of actual (and potentially greatly elevated) food security benefits from wild meat, the loss of tourism-based employment and the loss of wildlife heritage.

\section{Acknowledgements}

Thank you to Panthera, Zoological Society of London and Wild- life Conservation Society for hosting and providing financial sup- port for the bushmeat brainstorming meeting.

\section{References}

Albrechtsen, L., Fa, J., Barry, B., Macdonald, D., 2005. Contrasts in availability and consumption of animal protein in Bioko Island, West Africa: the role of bushmeat. Environmental Conservation 32, $340-348$.

Alexander, K.A., Blackburn, J.K., Vandewalle, M.E., Pesapane, R., Baipoledi, E.K., Elzer, P.H., 2012. Buffalo, Bush Meat, and the Zoonotic Threat of Brucellosis in Botswana. PLoS ONE 7, e32842.

Balakrishnan, M., Ndhlovu, D.E., 1992. Wildlife Utilization and Local People: A Case-study in Upper Lupande Game Management Area, Zambia. Environ. Conserv. 19, 135. 
Barnett, R., 2002. Wild meat utilisation in the east and southern Africa region, in: Mainka, S., Trivedi, M. (Eds.), Links between biodiversity conservation, livelihoods and food security: the sustainable use ofwild species for meat. IUCN, Gland.

Barnett, R., 2000. Food for Thought: The Utilisation of Wild Meat in Eastern and Southern Africa, TRAFFIC East/southern Africa, Nairobi.

Barnett, R., Patterson, C., 2006. Sport Hunting in the Southern African Development Community (SADC) Region: An overview, TRAFFIC East/Southern Africa, Johannesburg, South Africa.

Becker, M.S., McRobb, R., Watson, F., Droge, E., Kanyembo, B., Kakumbi, C., 2012. Evaluating wiresnare poaching trends and the impacts of by-catch on elephants and large carnivores. Biological Conservation. Biological Conservation, 158: 26-36.

Bennett, E.L., 2002. Is There a Link between Wild Meat and Food Security? Conserv. Biol. 16, 590592.

Bond, I., Child, B., De la Harpe, D., Jones, B., Barnes, J., Anderson, H., 2004. Private land contribution to conservation in southern Africa, in: Child, B. (Ed.), Parks in Transition: Biodiversity, Rural Development, and the Bottom Line. Earthscan, London.

Bouché, P., Nzapambetimange, R., Tankalet, F., Zowoya, F., Lejeune, P., Zowoya, F., 2012. Game over! Wildlife collapse in northern Central African Republic. Environmental Monitoring and Assessment.

Bowen-Jones, E., Brown, D., Robinson, E.J.Z., 2003. Economic commodity or environmental crisis? An interdisciplinary approach to analysing the bushmeat trade in central and west Africa. Area 35, 390402. 
Brashares, J., Goldena, C., Weinbauma, K., Barrettc, C., Okello, G., 2011. Economic and geographic drivers of wildlife consumption in rural Africa. Proceedings of the National Academy of Sciences 108, 13931-13936.

Brashares, J.S., Arcese, P., Sam, M.K., Coppolillo, P.B., Sinclair, A.R.E., Balmford, A., 2004. Bushmeat Hunting, Wildlife Declines, and Fish Supply in West Africa. Science 306, 1180-1183.

Brodie, J.F., Helmy, O.E., Brockelman, W.Y., Maron, J.L., 2009. Bushmeat poaching reduces the seed dispersal and population growth rate of a mammal-dispersed tree. Ecol. Appl. 19, 854-863.

Brown, D., 2007. Is the Best the Enemy of the Good? Institutional and Livelihoods Perspectives on Bushmeat Harvesting and Trade ? Some Issues and Challenges, in: Anonymous Bushmeat and Livelihoods: Wildlife Management and Poverty Reduction. Blackwell Publishing Ltd, pp. 111-124. Bruner, A.G., Gullison, R.E., Rice, R.E., da Fonseca, Gustavo A. B., 2001. Effectiveness of Parks in Protecting Tropical Biodiversity. Science 291, 125-128.

Chaber, A., Allebone-Webb, S., Lignereux, Y., Cunningham, A.A., Marcus Rowcliffe, J., 2010. The scale of illegal meat importation from Africa to Europe via Paris. Conservation Letters 3, 317-321.

Child, B. 2009. Community conservation in southern Africa: rights based natural resource management, in Child, B. (Ed.), Evolution and innovation in wildlife conservation. Earthscan, London, UK, pp.187-200.

Child, B., Castley, G., Knight, M., Gordan, J., Daitz, D., Johnson, S., Boonzaaier, W., Collinson, R., Davies, R., Grossman, D., and others, 2004. Innovations in park management, in: Child, B. (Ed.), Parks in transition. Earthscan, London, UK, pp. 165-188.

Cirelli, M., Morgera, E., 2009. Wildlife law in the southern African development community, FAO/CIC, Budapest, Hungary. 
Clark, C., Poulsen, J., Malonga, R., Elkan, P., 2009. Logging Concessions Can Extend the Conservation Estate for Central African Tropical Forests; Conserv. Biol. 23, 1281-1293.

Craigie, I.D., Baillie, J.E.M., Balmford, A., Carbone, C., Collen, B., Green, R.E., Hutton, J.M., 2010. Large mammal population declines in Africa's protected areas. Biol. Conserv. 143, 2221-2228.

Cumming, D., 2004. Performance of parks in a century of change, in: Child, B. (Ed.), Parks in Transition: Biodiversity, Rural Development, and the Bottom Line. Earthscan, UK.

de Merode, E., Smith, K.H., Homewood, K., Pettifor, R., Rowcliffe, M., Cowlishaw, G., 2007. The impact of armed conflict on protected-area efficacy in Central Africa. Biology Letters 3, 299-301.

Dickman, A.J., Macdonald, E.A., Macdonald, D.W., 2011. A review of financial instruments to pay for predator conservation and encourage humanâ€"carnivore coexistence. Proceedings of the National Academy of Sciences 108, 13937-13944.

Dobson, A.P., Borner, M., Sinclair, A.R.E., Hudson, P.J., Anderson, T.M., Bigurube, G., Davenport, T.B.B., Deutsch, J., Durant, S.M., Estes, R.D., and others, 2010. Road will ruin Serengeti. Nature 467, 272-273.

du Toit, R., 2004. Review of wildlife issues associated with the land reform programme in Zimbabwe, WWF-SARPO, Harare, Zimbabwe.

East, T., Kümpel, N.F., Milner-Gulland, E.J., Rowcliffe, J.M., 2005. Determinants of urban bushmeat consumption in Río Muni, Equatorial Guinea. Biol. Conserv. 126, 206-215.

Edderai, D., Dame, M., 2006. A census of the commercial bushmeat market in Yaoundé, Cameroon. Oryx 40, 472. 
Fa, J.E., Albrechtsen, L., Johnson, P.J., Macdonald, D.W., 2009. Linkages between household wealth, bushmeat and other animal protein consumption are not invariant: evidence from Rio Muni, Equatorial Guinea. Anim. Conserv. 12, 599-610.

Fa, J.E., Currie, D., Meeuwig, J., 2003. Bushmeat and food security in the Congo Basin: linkages between wildlife and people's future. Environ. Conserv. 30, 71.

Fa, J.E., Yuste, J.E.G., Castelo, R., 2000. Bushmeat Markets on Bioko Island as a Measure of Hunting Pressure; Mercados de Carne Silvestre en la Isla Bioko como Medida de la Presión por Caza. Conserv. Biol. 14, 1602-1613.

Feron, E., 1995. New food sources, conservation of biodiversity and sustainable development: can unconventional animal species contribute to feeding the world? Biodiversity and Conservation 4, 233-240.

Féron, E., Tafira, J., Belemsobgo, U., Blomme, S., De Garine- Wichatitsky, M., 1998. Transforming wild African herbivores into edible meat for local communities. Sustainable useof impala (Aepyceros melampus) in the CAMPFIRE Program, Zimbabwe. Revue D'Élevage Et De Médecine Vétérinaire Des Pays Tropicaux 51, 265-272.

Fischer, F., Linsenmair, K.E., 2001. Decreases in ungulate population densities. Examples from the Comoé National Park, Ivory Coast. Biol. Conserv. 101, 131-135.

Fitzgibbon, C., Mogaka, H., Fanshawe, J., 1995. Subsistence Hunting in Arabuko-Sokoke Forest, Kenya, and Its Effects on Mammal Populations. Conserv. Biol. 9, 1116-1126.

Foerster, S., Wilkie, D., Morelli, G., Demmer, J., Starkey, M., Telfer, P., Steil, M., Lewbel, A., 2012. Correlates of Bushmeat Hunting among Remote Rural Households in Gabon, Central Africa; Conserv. Biol. 26, 335-344. 
Fusari, A., Carpaneto, G., 2006. Subsistence hunting and conservation issues in the game reserve of Gile, Mozambique. Biodiversity and Conservation 3, 137-155.

Gandiwa, E., 2011. Preliminary assessment of illegal hunting by communities adjacent to the northern Gonarezhou National Park, Zimbabwe. Tropical Conservation Science 4(4), 445-467.

Goldman, M., 2003. Partitioned Nature, Privileged Knowledge: Community-based Conservation in Tanzania. Development and Change 34, 833-862.

Goldman, R.L., Tallis, H., Kareiva, P., Daily, G.C., 2008. Field evidence that ecosystem service projects support biodiversity and diversify options. Proceedings of the National Academy of Sciences 105, 9445-9448.

Grey-Ross, R., Downs, C.T., Kirkman, K., 2010. An Assessment of Illegal Hunting on Farmland in KwaZulu-Natal, South Africa: Implications for Oribi (Ourebia ourebi) Conservation. S. Afr. J. Wildl. Res. 40, 43-52.

Groom, B., Palmer, C., 2010. Environmental Services and Poverty Alleviation: Either, or, or Both? 2012.

Hatton, J., Couto, M., Oglethorpe, J., 2001. Biodiversity and war: a case study of Mozambique, WWF Biodiversity Support Program, Washington DC.

Haule, K.S., Johnsen, F.H., Maganga, S.L.S., 2002. Striving for sustainable wildlife management: the case of Kilombero Game Controlled Area, Tanzania. J. Environ. Manage. 66, 31-42.

Hayward, M.W., 2009. Bushmeat Hunting in Dwesa and Cwebe Nature Reserves, Eastern Cape, South Africa. S. Afr. J. Wildl. Res. 39, 70-84. 
Hayward, M.W., 2012. Perspectives on Fencing for Conservation Based on Four Case Studies: Marsupial Conservation in Australian Forests; Bushmeat Hunting in South Africa; Large Predator Reintroduction in South Africa; and Large Mammal Conservation in Poland. , 7-20.

Hilborn, R., Arcese, P., Borner, M., Hando, J., Hopcraft, G., Loibooki, M., Mduma, S., Sinclair, A.R.E., 2006. Effective Enforcement in a Conservation Area. Science 314, 1266-1266.

Hofer, H., Campbell, K., East, M., Huish, S., 1996. The impact of game meat hunting on target and non target species in the Serengeti, in: Taylor, V., Dunstone and N. (Eds.), Exploitation of mammal populations. Chapman \& Hall, Reading, UK, pp. 117-143.

Hofer, H., Campbell, K., East, M., Huish, S., 2000. Modelling the spatial distribution of the economic costs and benefits of illegal game meat hunting in the Serengeti. Nat. Resour. Model. 13, 151-177.

Holmern, T., Muya, J., Oslash, R., Skaft, E., 2007. Local law enforcement and illegal bushmeat hunting outside the Serengeti National Park, Tanzania. Environ. Conserv. 34, 55.

Holmern, T., Roslash, E., Mbaruka, J., Mkama, S., Muya, , 2002. Uneconomical game cropping in a community-based conservation project outside the Serengeti National Park, Tanzania. Oryx 36, 364.

Holmes, G., 2007. - Protection, Politics and Protest: Understanding Resistance to Conservation. Conservat Soc - 5, - 184-- 201.

Jachmann, H., Billiouw, M., 1997. Elephant poaching and law enforcement in the Central Luangwa Valley, Zambia. Journal of Applied Ecology 34, 234-244.

Jachmann, H., 2008a. Illegal wildlife use and protected area management in Ghana. Biol. Conserv. $141,1906-1918$. 
Jachmann, H., 2008b. Monitoring law-enforcement performance in nine protected areas in Ghana. Biol. Conserv. 141, 89-99.

Jambiya, G., Milledge, S., Mtango, N., 2007. 'Night Time Spinach': Conservation and livelihood implications of wild meat use in refugee situations in north-western Tanzania, TRAFFIC East/Southern Africa, Dar es Salaam, Tanzania.

Jones, B., 2007. Synthesis of the CBNRM policy and legislation in Botswana, Malawi, Mozambique, Zambia and Zimbabwe, WWF-SARPO, Harare, Zimbabwe.

Joppa, L.N., Loarie, S.R., Pimm, S.L., 2009. On Population Growth Near Protected Areas. PLoS ONE 4, e4279.

Keane, A., Jones, J.P.G., Edwards-Jones, G., Milner-Gulland, E.J., 2008. The sleeping policeman: understanding issues of enforcement and compliance in conservation. Anim. Conserv. 11, 75-82.

Kiringe, J.W., Okello, M.M., Ekajul, S.W., 2007. Managers' perceptions of threats to the protected areas of Kenya: prioritization for effective management. Oryx 41, 314.

Knapp, E.J., 2007. Who Poaches? Household Economies of Illegal Hunters in Western Serengeti, Tanzania. Human Dimensions of Wildlife 12, 195-196.

Le Bel, S., Gaidet, N., Mutake, S., Doze, L., Nyamugure, T., 2004. Communal game ranching in Zimbabwe: local empowerment and sustainable game meat production for rural communities. Game and Wildlife Science 21, 275-290.

Leader-Williams, N., Milner-Gulland, E.J., 1993. Policies for the Enforcement of Wildlife Laws: The Balance between Detection and Penalties in Luangwa Valley, Zambia. Conserv. Biol. 7, 611-617. 
Lewis, D., 2005. Synergies between animal husbandry and wildlife conservation: perspectives from Zambia, in: Osofsky, O., Cleaveland, S., Karesh, W., et al (Eds.), Conservation and development interventions at the wildlife/livestock interfaceimplications for wildlife, livestock and human health. IUCN, Gland, Switzerland.

Lewis, D., Phiri, A., 1998. Wildlife snaring - an indicator of community response to a communitybased conservation project. Oryx 32, 111-121.

Lewis, D., Bell, S.D., Fay, J., Bothi, K.L., Gatere, L., Kabila, M., Mukamba, M., Matokwani, E., Mushimbalume, M., Moraru, C.I., and others, 2011. Community Markets for Conservation (COMACO) links biodiversity conservation with sustainable improvements in livelihoods and food production. Proceedings of the National Academy of Sciences 108, 13957-13962.

Lindsey, P., Balme, G., Booth, V., Midlane, N., 2012. The Significance of African Lions for the Financial Viability of Trophy Hunting and the Maintenance of Wild Land. PLoS One , - e29332.

Lindsey, P., Bento, C., 2012. Illegal Hunting and the Bushmeat Trade in Central Mozambique. A Casestudy from Coutada 9, Manica Province. TRAFFIC East/Southern Africa, Harare, Zimbabwe.

Lindsey, P., Havemann, C., Lines, L., Price, A., Retief, T., Rhebergen, T., van der Waal, C., Romañach, S., In press. Benefits of wildlife-based land uses on private land in Namibia and limitations affecting their development. Oryx.

Lindsey, P., Alexander, R., Balme, G., Midlane, N., Craig, J., 2012. Possible Relationships between the South African Captive-Bred Lion Hunting Industry and the Hunting and Conservation of Lions Elsewhere in Africa. S. Afr. J. Wildl. Res. 42, 11-22.

Lindsey, P.A., Roulet, P.A., Romañach, S.S., 2007. Economic and conservation significance of the trophy hunting industry in sub-Saharan Africa. Biol. Conserv. 134, 455-469. 
Lindsey, P.A., Romañach, S.S., Tambling, C.J., Chartier, K., Groom, R., 2011a. Ecological and financial impacts of illegal bushmeat trade in Zimbabwe. Oryx 45, 96.

Lindsey, P.A., Romañach, S.S., Matema, S., Matema, C., Mupamhadzi, I., Muvengwi, J., 2011b.

Dynamics and underlying causes of illegal bushmeat trade in Zimbabwe. Oryx 45, 84.

Lindsey, P.A., Masterson, C.L., Beck, A.L., Romañach, S., 2012. Ecological, Social and Financial Issues Related to Fencing as a Conservation Tool in Africa, in: Somers, M.J., Hayward, M. (Eds.), Fencing for Conservation. Springer New York, pp. 215-234.

Loibooki, M., Hofer, H., Campbell, K.L.I., East, M.L., 2002. Bushmeat hunting by communities adjacent to the Serengeti National Park, Tanzania: the importance of livestock ownership and alternative sources of protein and income. Environ. Conserv. 29, 391.

Manousrian, S., Dudley, N., 2008. Public fund to protected areas, WWF, Gland, Switzerland.

Marealle, W.N., FossÃ ,y, F., Holmern, T., Stokke, B., RÃ,skaft, E., 2010. Does illegal hunting skew Serengeti wildlife sex ratios? Wildl. Biol. 16, 419-429.

Martin, E., 1996. The importance of park budgets, intelligence networks andcompetent managers for successful conservation of the greater one-horned rhinoceros. Pachyderm 22.

Mockrin, M., Rockwell, R., Redford, K., Keuler, N., 2011. Effects of Landscape Features on the Distribution and Sustainability of Ungulate Hunting in Northern Congo. Conserv. Biol. 25, 514-525.

Montag, J., 2003. Compensation and predator conservation: Limitations of compensation. Carnivore Damage Prevention News 6, 2-6.

Moyo, D., 2009. Dead aid: why aid is not working and how there is a better way for Africa, Farrar, Straus and Giroux, New York, USA. 
Muchaal, P.K., Ngandjui, G., 1999. Impact of Village Hunting on Wildlife Populations in the Western Dja Reserve, Cameroon. Conserv. Biol. 13, 385-396.

Muriuki, G.W., Njoka, T.J., Reid, R.S., Nyariki, D.M., 2005. Tsetse control and land-use change in Lambwe valley, south-western Kenya. Agric. , Ecosyst. Environ. 106, 99-107.

Nasi, R., Brown, D., Wilkie, D., Bennett, E., Tutin, C., van Tol, G., Christophersen, T., 2008.

Conservation and use of wildlife-based resources: the bushmeat crisis. Technical Series no.33.

Secretariat of the Convention on Biological Diversity, Montreal, and Center for International Forestry Research (CIFOR), Bogor, Indonesia.

Naughton-Treves, L., Holland, M.B., Brandon, K., 2005. The role of protected areas in conserving biodiversity and sustaining local livelihoods. Annu. Rev. Environ. Resourc. 30, 219-252.

Ndibalema, V.G., Songorwa, A.N., 2008. Illegal meat hunting in serengeti: dynamics in consumption and preferences. Afr. J. Ecol. 46, 311-319.

Newmark, W.D., 2008. Isolation of African protected areas. Frontiers in Ecology and the Environment 6, 321-328.

Nielsen, M.R., 2006. Importance, cause and effect of bushmeat hunting in the Udzungwa Mountains, Tanzania: Implications for community based wildlife management. Biol. Conserv. 128, 509-516.

Noss, A.J., 1998. The Impacts of Cable Snare Hunting on Wildlife Populations in the Forests of the Central African Republic. Conserv. Biol. 12, 390-398.

Norton-Griffiths, M. 2007. How many wildebeest do you need? World Economics. 8(2), 41-62.

Nyahongo, J.W., East, J.W., Mturi, F.A., Hofer, H., 2005. Benefits and costs of illegal grazing and hunting in the Serengeti ecosystem. Environ. Conserv. 32, 326. 
Ogutu, J.O., Piepho, H.-., Dublin, H.T., Bhola, N., Reid, R.S., 2009. Dynamics of Mara?Serengeti ungulates in relation to land use changes. J. Zool. 278, 1-14.

Okello, M.M., Kiringe, J.W., 2004. Threats to Biodiversity and their Implications in Protected and Adjacent Dispersal Areas of Kenya. Journal of Sustainable Tourism 12, 55-69.

Parker, I., 1986. Perspectives on Wildlife Cropping or Culling. Chapter 16 in: Conservation and Wildlife Management in Africa. in: Bell, R., McShane-Caluzi, E. (Eds.), Proceedings of a workshop sponsored by the US Peace Corps, Kasungu National Park, Malawi, 1984. Peace Corps, Washington, USA.

Poulsen, J.R., Clark, C.J., Mavah, G., Elkan, P.W., 2009. Bushmeat Supply and Consumption in a Tropical Logging Concession in Northern Congo. Conserv. Biol. 23, 1597-1608.

Redford, K., 1992. The empty forest. Bioscience 42, 412-422.

Renaud, P., 2011. Inventaire aérien et terrestre de la faune et relevé des pressions au Parc National du Niokolo Koba, African Parks Network.

Riggio, J., Jacbson, A., Dollar, L., Bauer, H., Becker, M., Dickman, A., Funston, P., Groom, R., Henschel, P., de Longh, H., Lichtenfeld, L., Pimm, S. 2012. The size of savannah Africa: a lion's (Panthera leo) view. Biodiversity and Conservation. DOI 10.1007/s10531-012-0381-4.

Rist, J., Milner-Gulland, E.J., Cowlishaw, G., Rowcliffe, M., 2010. Hunter Reporting of Catch per Unit Effort as a Monitoring Tool in a Bushmeat-Harvesting System. Conserv. Biol. 24, 489-499.

Robinson, J.G., Bennett, E.L., 2004. Having your wildlife and eating it too: an analysis of hunting sustainability across tropical ecosystems. Anim. Conserv. 7, 397-408. 
Ronnback, P., Bryceson, I., Kautsky, N., 2002. Coastal Aquaculture Development in Eastern Africa and the Western Indian Ocean: Prospects and Problems for Food Security and Local Economies. AMBIO: A Journal of the Human Environment 31, 537-542.

Rowcliffe, J.M., de Merode, E., Cowlishaw, G., 2004. Do wildlife laws work? Species protection and the application of a prey choice model to poaching decisions. Proceedings of the Royal Society of London. Series B: Biological Sciences 271, 2631-2636.

Saru, E., 2012. Challenges, gaps and ongoing interventions in combating bush meat in Kenya. 2012.

Scholte, P., 2011. Towards understanding large mammal population declines in Africa's protected areas: A West-Central African perspective. Tropical Conservation Science 4, 1-11.

Secretariat of the Convention on Biological Diversity, 2011. Sustainable use of biodiversity: revised recommendations of the LiaisonGroup on Bushmeat, including options for small-scale food and incomealternatives, and report on how to improve sustainable use in alandscape perspective.

Simasiku, P., Simwanza, H., Tembo, G., Bandyopadhyay, S., Pavy, J., 2008. The impact of wildlife management policies on communities and conservation in Game Management Areas in Zambia, Natural Resources Consultative Forum, Zambia.

Stiles, D., 2011. Elephant meat and ivory trade in Central Africa. Pachyderm 50, 26-36.

Stokes, E.J., Strindberg, S., Bakabana, P.C., Elkan, P.W., Iyenguet, F.C., MadzokÃ@, B., Malanda, G.A.F., Mowawa, B.S., Moukoumbou, C., Ouakabadio, F.K., and others, 2010. Monitoring Great Ape and Elephant Abundance at Large Spatial Scales: Measuring Effectiveness of a Conservation Landscape. PLoS ONE 5, e10294. 
Stoner, C., Caro, T., Mduma, S., Mlingwa, C., Sabuni, G., Borner, M., 2007. Assessment of

Effectiveness of Protection Strategies in Tanzania Based on a Decade of Survey Data for Large

Herbivores. Conserv. Biol. 21, 635-646.

Stuart-Hill, G., Diggle, R., Munali, B., Tagg, J., Ward, D., 2005. The event book system: a communitybased natural resource monitoring system from Namibia. Biodiversity and Conservation 14, 26112631.

Suich, H., Child, B., Spenceley, A., 2009. Evolution and innovation in wildlife conservation: parks and game ranches to transfrontier conservation areas, Earthscan.

van der Westhuizen, H., 2007. Evaluating law enforcement and illegal wildlife use in the northern Luangwa Valley, Zambia.

Van Vliet, N., 2011. Livelihood alternatives for the unsustainable use of bushmeat. Report prepared for the CBD Bushmeat Liaison Group. Technical Serices No. 60, Montreal, SCBD, 1-46.

Warchol, G., Johnson, B., 2009. Wildlife Crime in the Game Reserves of South Africa: A Research Note. Int. J. Comp. Appl. Crim. Justice 33, 143-154.

Wato, Y.A., Wahungu, G.M., Okello, M.M., 2006. Correlates of wildlife snaring patterns in Tsavo West National Park, Kenya. Biol. Conserv. 132, 500-509.

Weaver, C., 2011. The catalytic role and contributions of sustainable wildlife use to the Namibia CBNRM Programme, in: Abensperg-Traun, M., Roe, D. and O'Criodain, C. (Eds.), CITES and CBNRM. Proceedings of an international symposium on "The relevance of CBNRM to the conservation and sustainable use of CITES-listed species in exporting countries", Vienna, Austria, 18-20 May 2011. IUCN, Gland, Switzerland, pp. 1-172. 
Wilfred, P., MacColl, A., 2010. Income sources and their relation to wildlife poaching in Ugalla ecosystem, Western Tanzania. African Journal of Environmental Science and Technology 4, 886-896.

Wilkie, D., Starkey, M., Abernethy, K., Effa, E., Telfer, P., Godoy, R., 2005. Role of Prices and Wealth in Consumer Demand for Bushmeat in Gabon, Central Africa. Conserv. Biol. 19, 268-274.

Wilkie, D.S., Carpenter, J., 1999. The potential role of safari hunting as a source of revenue for protected areas in the Congo Basin. Oryx 33, 340-345.

Wilkie, D.S., Bennett, E.L., Peres, C.A., Cunningham, A.A., 2011. The empty forest revisited. Ann. N. Y. Acad. Sci. 1223, 120-128.

Wilkie, D.S.S., 1999. Bushmeat hunting in the Congo Basin: an assessment of impacts and options for mitigation. Biodivers. Conserv. 8, 927-955.

Wittemyer, G., Elsen, P., Bean, W.T., Burton, A.C.O., Brashares, J.S., 2008. Accelerated Human Population Growth at Protected Area Edges. Science 321, 123-126.

World Bank, 2012. Zambian wildlife sector policy: impact analysis and recommendations for the future policy, Africa Technical Environment and Natural Resources Unit, World Bank, Lusaka, Zambia.

Wright, S.J., Stoner, K.E., Beckman, N., Corlett, R.T., Dirzo, R., Muller-Landau, H.C., Nuñez-Iturri, G., Peres, C.A., Wang, B.C., 2007. The Plight of Large Animals in Tropical Forests and the Consequences for Plant Regeneration. Biotropica 39, 289-291.

Zambia Central Statistical Office, 2011. 2010 census of population and housing: preliminary population figures, Government of Zambia, Lusaka, Zambia. 